Nat. Hazards Earth Syst. Sci., 18, 3383-3402, 2018

https://doi.org/10.5194/nhess-18-3383-2018

(C) Author(s) 2018. This work is distributed under

the Creative Commons Attribution 4.0 License.

\title{
Analysis of the risk associated with coastal flooding hazards: a new historical extreme storm surges dataset for Dunkirk, France
}

\author{
Yasser Hamdi ${ }^{1}$, Emmanuel Garnier ${ }^{2}$, Nathalie Giloy ${ }^{1}$, Claire-Marie Duluc ${ }^{1}$, and Vincent Rebour ${ }^{1}$ \\ ${ }^{1}$ Institute for Radiation Protection and Nuclear Safety, BP17, 92262 Fontenay-aux-Roses CEDEX, France \\ ${ }^{2}$ UMR 6249 CNRS Chrono-Environnement, University of Besançon, Besançon, France
}

Correspondence: Yasser Hamdi (yasser.hamdi@irsn.fr)

Received: 23 November 2017 - Discussion started: 5 December 2017

Revised: 7 November 2018 - Accepted: 13 November 2018 - Published: 21 December 2018

\begin{abstract}
This paper aims to demonstrate the technical feasibility of a historical study devoted to French nuclear power plants (NPPs) which can be prone to extreme coastal flooding events. It has been shown in the literature that the use of historical information (HI) can significantly improve the probabilistic and statistical modeling of extreme events. There is a significant lack of historical data on coastal flooding (storms and storm surges) compared to river flooding events. To address this data scarcity and to improve the estimation of the risk associated with coastal flooding hazards, a dataset of historical storms and storm surges that hit the Nord-Pasde-Calais region during the past five centuries was created from archival sources, examined and used in a frequency analysis (FA) in order to assess its impact on frequency estimations. This work on the Dunkirk site (representative of the Gravelines NPP) is a continuation of previous work performed on the La Rochelle site in France. Indeed, the frequency model (FM) used in the present paper had some success in the field of coastal hazards and it has been applied in previous studies to surge datasets to prevent coastal flooding in the La Rochelle region in France.

In a first step, only information collected from the literature (published reports, journal papers and $\mathrm{PhD}$ theses) is considered. Although this first historical dataset has extended the gauged record back in time to 1897 , serious questions related to the exhaustiveness of the information and about the validity of the developed FM have remained unanswered. Additional qualitative and quantitative $\mathrm{HI}$ was extracted in a second step from many older archival sources. This work has led to the construction of storm and coastal flooding sheets summarizing key data on each identified event. The quality control and the cross-validation of the collected in-
\end{abstract}

formation, which have been carried out systematically, indicate that it is valid and complete in regard to extreme storms and storm surges. Most of the HI collected is in good agreement with other archival sources and documentary climate reconstructions. The probabilistic and statistical analysis of a dataset containing an exceptional observation considered as an outlier (i.e., the 1953 storm surge) is significantly improved when the additional $\mathrm{HI}$ collected in both literature and archives is used. As the historical data tend to be extreme, the right tail of the distribution has been reinforced and the 1953 "exceptional" event does not appear as an outlier any more. This new dataset provides a valuable source of information on storm surges for future characterization of coastal hazards.

\section{Introduction}

As the coastal zone of the Nord-Pas-de-Calais region in northern France is densely populated, coastal flooding represents a natural hazard threatening the costal populations and facilities in several areas along the shore. The Gravelines nuclear power plant (NPP) is one of those coastal facilities. It is located near the community of Gravelines in northern France, approximately $20 \mathrm{~km}$ from Dunkirk and Calais. The Gravelines NPP is the sixth largest nuclear power station in the world, the second largest in Europe and the largest in Western Europe.

Extreme weather conditions could induce strong surges that could cause coastal flooding. The 1953 North Sea flood was a major flood caused by a heavy storm that occurred on the night of Saturday, 31 January and morning of Sun- 
(a)

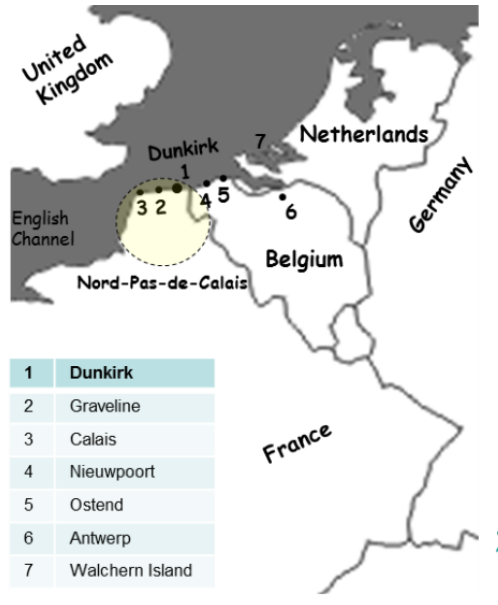

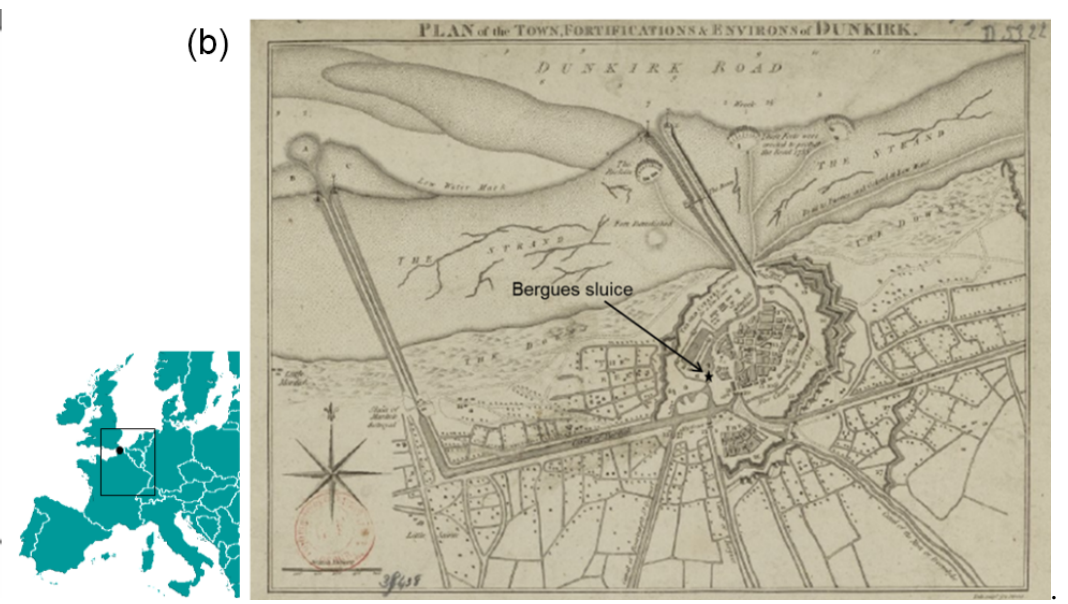

Figure 1. Map of the location (a) and an old plan of the Dunkirk city with the measure point of Bergues sluice (b)

day, 1 February. The floods struck many European countries and France was no exception. It hit particularly hard along the northern coast of France, from Dunkirk to the Belgian border. Indeed, it has been shown in an unpublished study that Dunkirk is fairly representative of the Gravelines NPP in terms of extreme sea levels. In addition, the harbor of Dunkirk is an important military base containing a lot of archives. The site of Dunkirk has therefore been selected as site of interest in the present paper (Fig. 1). An old map of Dunkirk city is presented in Fig. 1b (we shall return to this map at a later stage in this paper). It is a common belief today that the Dunkirk region is vulnerable and subject to several climate risks (e.g., Maspataud et al., 2013). More severe coastal flooding events, such as the November 2007 North Sea and the March 2008 Atlantic storms, could have had much more severe consequences especially if they had occurred at high tide (Maspataud et al., 2013; Idier et al., 2012). It is important for us to take into account the return periods of such events (especially in the current context of global climate change and projected sea-level rise) in order to manage and reduce coastal hazards, implement risk prevention policies and enhance and strengthen coastal defence against coastal flooding.

The storm surge frequency analysis (FA) represents a key step in the evaluation of the risk associated with coastal hazards. The frequency estimation of extreme events (induced by natural hazards) using probability functions has been extensively studied for more than a century (e.g., Gumbel, 1935; Chow, 1953; Dalrymple, 1960; Hosking and Wallis, 1986, 1993, 1997; Hamdi et al., 2014, 2015). We generally need to estimate the risk associated with an extreme event in a given return period. Most extreme value models are based on available at-site recorded observations only. A common problem in FA and estimation of the risk associated with extreme events is the estimation from a relatively short gauged record of the flood corresponding to $100-1000$ year return periods. The problem is even more complicated when this short record contains an outlier (an observation much higher than any others in the dataset). This is the case with several sea-level time series in France and characterizes the Dunkirk surge time series as well.

The 1953 storm surge was considered as an outlier in our previous work (Hamdi et al., 2014) and in previous research (e.g., Bardet et al., 2011). Indeed, although the Gravelines NPP is designed to sustain very low probabilities of failure and despite the fact that no damage was reported at the French NPPs, the 1953 coastal flooding had shown that the extreme sea levels estimated with the current statistical approaches could be underestimated. It seems that the local FA is not really suitable for a relatively short dataset containing an outlier.

Indeed, a poor estimation of the distribution parameters may be related to the presence of an outlier in the sample (Hamdi et al., 2015), and must be properly addressed in the FA. One would expect that one or more additional extreme events in a long period (500 years for instance) would, if properly included in the frequency model (FM), improve the estimation of a quantile at the given high-return period. The use of other sources of information with more appropriate FMs is required in the frequency estimation of extremes. Worth noting is that this recommendation is not new and dates back several years. The value of using other sources of data in the FA of extreme events has been recognized by several authors (e.g., Hosking and Wallis, 1986; Stedinger and Cohn, 1986). Through other sources of information, we are able to refer here to events that occurred not only before the systematic period (gauging period) but also during gaps of the recorded time series. Water marks left by extreme floods, damage reports and newspapers are reliable sources of historical information (HI). It can also be found in the literature, archives, unpublished written records, etc. It may also arise from verbal communications from the general public. Pale- 
oflood and dendrohydrology records (the analysis and application of tree-ring records) can be useful as well. A literature review on the use of $\mathrm{HI}$ in flood FAs with an inventory of methods for its modeling has been published by Ouarda et al. (1998). Attempts to evaluate the usefulness of HI for the frequency estimation of extreme events are numerous in the literature (e.g., Guo and Cunnane, 1991; Ouarda et al., 1998; Gaal et al., 2010; Payrastre et al., 2011; Hamdi, 2011; Hamdi et al., 2015). Hosking and Wallis (1986) have assessed the value of $\mathrm{HI}$ using simulated flood series and historical events generated from an extreme value distribution and quantiles are estimated by the maximum likelihood method with and without the historical event. The accuracy of the quantile estimates was then assessed and it was concluded that $\mathrm{HI}$ is of great value provided either that the flood frequency distribution has at least three unknown parameters or that gauged records are short. It was also stated that the inclusion of $\mathrm{HI}$ is unlikely to be useful in practice when a large number of sites are used in a regional context. Data reconstructed using HI are often imprecise, and we should consider their inaccuracy in the analysis (by using thresholds of perception, range and lower bound data, etc.). However, as it was shown in the literature, even with important uncertainty, the use of $\mathrm{HI}$ is a viable means of decreasing the influence of outliers by increasing their representativeness in the sample (Hosking and Wallis, 1986; Wang, 1990; Salas et al., 1994; Payrastre et al., 2011). A frequency estimation of extreme storm surges based on the use of $\mathrm{HI}$ has rarely been studied explicitly in the literature (Bulteau et al., 2015; Hamdi et al., 2015) despite its significant impact on social and economic activities and on NPPs' safety. Bulteau et al. (2015) have estimated extreme sea levels by applying a Bayesian model to the La Rochelle site in France. This same site was used as a case study by Hamdi et al. (2015) to characterize the coastal flooding hazard. The use of a skew surge series containing an outlier in local frequency estimation is limited in the literature as well. For convenience, we would like to recall here the definition of a skew surge: it is the difference between the maximum observed water level and the maximum predicted tidal level regardless of their timing during the tidal cycle (a tidal cycle contains one skew surge).

It is often possible to augment the storm surges record with those that occurred before and after gauging began. Before embarking on a thorough and exhaustive research of any HI related to coastal flooding that hit the area of interest, potential sources of historical coastal flooding data for the French coast (Atlantic and English Channel) and more specifically for the Charente-Maritime region were identified in the literature (e.g., Garnier and Surville, 2010). The HI collected has been very helpful in the estimation of extreme surges at La Rochelle, which was heavily affected by the storm Xynthia in 2010 that generated a water level that has so far been considered as an outlier (Hamdi et al., 2015). Indeed, these results for the La Rochelle site have encouraged us to build a more complete historical database covering all the extreme coastal flooding that occurred over the past five centuries on the French coast (Atlantic and English Channel). This database has been completed and is currently the subject of a working group involving several French organizations for maintenance. However, only the historical storm surges that hit the Nord-Pas-de-Calais region during this period are presented herein.

The main objective of the present work is the collection of $\mathrm{HI}$ on storms and storm surges that occurred in the last five centuries and to examine its impact on the frequency estimation of extreme storm surges. The paper is organized as follows: HI collected in the literature and its impact on the FA results is presented in Sects. 2 and 3. Section 4 presents the HI recovered from archival sources, the quality control thereof and its validation. In Sect. 5, the FM is applied using both literature and archival sources. The results are discussed in the same section before concluding and presenting some perspectives in Sect. 6 .

\section{Use of HI to improve the frequency estimation of extreme storm surges}

The systematic storm surge series is obtained from the corrected observations and predicted tide levels. The tide gauge data is managed by the French Oceanographic Service (SHOM - Service Hydrographique et Océanographique de la Marine) and measurements are available since 1956. The R package TideHarmonics (Stephenson, 2017) is used to calculate the tidal predictions. In order to remove the effect of sea level rise, the initial mean sea level (obtained by tidal analysis) is corrected for each year by using an annual linear regression, before calculating the predictions. The regression is obtained by calculating daily means using a Demerliac filter (Simon, 2007). Monthly and annual means are calculated with respect to the Permanent Service for Mean Sea Level (PSMSL) criteria (Holgate et al., 2013). This method is inspired by the method used by SHOM for its analysis of high water levels during extreme events (SHOM, 2015). The available systematic surge dataset was obtained for the period from 1956 to 2015.

The effective design of coastal defense is dependent on how high a design quantile (1000-year storm surge for instance) will be. But this is always estimated with uncertainty and not precisely known. Indeed, any frequency estimation is given with a confidence interval (CI) of which the width depends mainly on the size of the sample used in the estimation. Some other sources of uncertainties (such as the use of trends related to climate change) can be considered in the frequency estimation (Katz et al., 2002). As mentioned in the introductory section, samples are often short and characterized by the presence of outliers. The CIs are rather large and in some cases more than 2 or 3 times (and even more) the value of the quantile. Using the upper limit of this CI would likely lead to a more expensive design of the defensive struc- 
ture. One could just use the most likely estimate and neglect the $\mathrm{CI}$ but it is more interesting to consider the uncertainty as often estimated in frequency analyses. The width of the CI (i.e., inversely related to the sample size) can be reduced by increasing the sample size. In the present work, we focus on increasing the number of observations by adding information about storm surges induced by historical events. Additional storm surges can be subdivided into two groups:

1. HI during gaps in systematic records;

2. HI before the gauging period (can be found in the literature and/or collected by historians in archives).

\section{HI during and before the gauging period}

A historical research devoted to the French NPPs located on the Atlantic and English Channel coast was a genuine scientific challenge due to the time factor and the geographic dispersion of the nuclear sites. To be considered in the FA, a historical storm surge must be well documented; its date must be known and some information on its magnitude must be available. Mostly, available information concerns the impact and the societal disruption caused at the time of the event (Baart et al., 2011).

\subsection{HI collected in the literature}

As mentioned above, a common issue in frequency estimations is the presence of gaps within the datasets. Failure of the measuring devices and damage, mainly caused by natural hazards (storms, for instance), are often the origin of these gaps. Human errors, strikes, wars, etc., can also give rise to these gaps. Nevertheless, these gaps are themselves considered as dependent events. It is therefore necessary to ensure that the occurrence of the gaps and the observed variable are independent. Whatever the origin and characteristics of the missing period, the use of the full set of extreme storm surges that occurred during the gaps is strongly recommended to ensure the exhaustiveness of the information. This will make the estimates more robust and reduce associated uncertainties. Indeed, by delving into the literature and the web, one can obtain more information about this kind of events. Maspataud (2011) was able to collect sea-level measurements that were taken by regional maritime services during a storm event in the beginning of 1995, a time where the Dunkirk tide gauge was not working. This allowed the calculation of the skew surge, which was estimated by the author at $1.15 \mathrm{~m}$ on 2 January 1995 . This storm surge is high enough to be considered as an extreme event. In fact, it was exceeded only twice during the systematic period (5 January 2012 and 6 December 2013).

In the relatively short-term pre-gauging period, a literature review was conducted in order to get an overview of the storm events and associated surges that hit the Nord-Pas-deCalais region in France during the last two centuries. The following documents and storm databases on local, regional or national scales are available.

- The "Plan de Prévention de Risques Littoraux (PPRL)": refers to documents made by the French state on a communal scale, describing the risks a coastal zone is subject to, e.g., coastal flooding and erosion, and preventive measures in case of a hazard happening. To highlight the vulnerability of a zone, an inventory of storms and coastal inundation within the considered area is attached to this document.

- Deboudt (1997) and Maspataud (2011) describe the impact of storms on coastal areas for the study region.

- The VIMERS Project gives information on the evolutions of the Atlantic depressions that hit Brittany (DREAL Bretagne, 2017).

- The NIVEXT Project presents historical tide gauge data and the corresponding extreme water and surge levels for storm events (SHOM, 2015).

- Lamb (1991) provides synoptic reconstructions of the major storms that hit the British Isles from the 16th century up until today.

According to the literature, the storm of 31 January to 1 February 1953 caused the greatest surge and was the most damaging within the study area. This event has been well analyzed and documented (Sneyers, 1953; Rossiter, 1953; Gerritsen, 2005; Wolf and Flather, 2005): a depression formed over the northern Atlantic Ocean close to Iceland moving eastward over Scotland and then changing its direction to southeastwards over the North Sea, accompanied by strong northerly winds. An important surge was generated by this storm that, in conjunction with a high spring tide, resulted in particularly high sea levels. Around the southern parts of the North Sea the maximum surges exceeded $2.25 \mathrm{~m}$, reaching $3.90 \mathrm{~m}$ at Harlingen, Netherlands. Large areas were flooded in Great Britain, northern parts of France, Belgium, the Netherlands and the German Bight, causing the death of more than 2000 people. Le Gorgeu and Guitonneau (1954) indicate that during this event, the water level exceeded the predicted water level at the eastern dyke of Dunkirk by more than $2.40 \mathrm{~m}$ (Table 1). Bardet et al. (2011) included a storm surge equal to $2.13 \mathrm{~m}$ in their regional frequency analysis. Both authors indicate the same observed water level, i.e., $7.90 \mathrm{~m}$, but the predicted water level differs: while in 1954 the predicted water level was estimated at $5.50 \mathrm{~m}$, the predictions were reevaluated to $5.77 \mathrm{~m}$ by the SHOM using the harmonic method (SHOM, 2016). A storm surge of $2.13 \mathrm{~m}$ is therefore used in the present study. Nevertheless, as also shown in Table 1, some other storms (1897, 1949 and 1995) that induced important storm surges and coastal floods occurred within the area of interest. Appendix A presents a description of these events which are 
Table 1. Date, localization, water and surge levels (m) of collected storms within Nord-Pas-de-Calais area.

\begin{tabular}{llllll}
\hline Date & Location & $\begin{array}{l}\text { Predicted } \\
\text { WL }\end{array}$ & $\begin{array}{l}\text { Observed } \\
\text { WL }\end{array}$ & Surge & Source \\
\hline 28 Nov 1897 & Malo-les-Bains Dunkirk & $5.50^{1}$ & $7.36^{1}$ & $1.86^{1}$ & DREAL Nord (2017) \\
\hline 1 Mar 1949 & Dunkirk & 5.70 NGF & $7.30 \mathrm{NGF}^{2}$ & 1.60 & Le Gorgeu and Guitonnau (1954) \\
& & & $7.55 \mathrm{NGF}^{2}$ & 1.85 & DREAL Nord (2017) \\
\hline \multirow{2}{*}{ 1 Feb 1953 } & Antwerp (BE) & - & $>7 \mathrm{TAW}^{3}$ & - & Codde and De Keyser (1967) \\
& Sangatte, Calais & 6.70 & 8.20 & 1.50 & Deboudt (1997) \\
& Dunkirk & 5.50 & 7.90 & 2.40 & Le Gorgeu and Guitonnau (1954) \\
& Dunkirk & 5.77 & 7.90 & 2.13 & Bardet et al. (2011) \\
\hline
\end{tabular}

${ }^{1}$ No reference leveling given. ${ }^{2}$ NGF: the French Ordnance Datum (Nivellement Général Français). ${ }^{3}$ TAW: Tweede Algemeene Waterpassing (a reference level used in Belgium for water levels).

quite well documented in the literature. In the Appendix, a description of some other historical events (of which the information provided did not allow the estimation of a storm surge value) is included as well.

\subsection{HI collected in the archives}

For the longer term, the $\mathrm{HI}$ collection process involves the exploration and consultation, in a context of a permanent multi-scalar approach, of $\mathrm{HI}$ which can be seen as a real documentary puzzle with a large number of historical sources and archives. Indeed, NPPs are generally located, for obvious safety reasons, in sparsely populated and isolated areas which is why these sites were subject to little anthropogenic influence in the past. However, this difficulty does not forfeit a historical perspective due to the rich documentary resources for studying an extreme event on different scales, ranging from the site itself to that of the region (Garnier, 2015, 2017, 2018). In addition, this may be an opportunity for researchers and a part of the solution because it also allows a risk assessment at ungauged sites.

First, it is important to distinguish between "direct data" (also referred to as "direct evidence") and "indirect data" (also referred to as "proxy data"). The first refers to all information from the archives that describes an extreme event (a storm surge event for instance) that occurred at a known date. If their content is mostly instrumental, such as meteorological records presented in certain ordinary books or by the Paris Observatory (since the 17th century), sometimes accurate descriptions of extreme climatic events are likewise found. The "proxy data" rather indicate the influence of certain storm initiators and triggers such as wind and pressure. Concretely, they provide information indirectly on coastal flooding for example.

Private documents or "ego-documents" (accounts and ordinary books, private diaries, etc.) are used in many ways during 16th to 19th centuries. Authors recorded local facts, short news and latest events, and amongst them, weather incidents. These misidentified historical objects may contain a lot of valuable meteorological data. These private documents most often take the form of a register or a journal in which the authors record various events (economic, social and political) as well as weather information. Other authors use a more integrated approach to describe a weather event by combining observations of extreme events, instrumental information, phenology (impact on harvests), prices in local markets and possibly its social expression (scarcity, emotions, riots, etc.). All these misidentified sources are another opportunity for risk and climate historians to better understand the natural and coastal hazards (coastal flooding, earthquakes, tsunamis, landslides, etc.) of the past. Some of these private documents may be limited to weather tables completely disconnected from their socio-economic and climatic contexts. Most of the consulted documents and archives describe the history of coastal flooding in the area of interest. Indeed, the historical inventory identifies and describes damaging coastal flooding that occurred on the northern coast of France (Nord-Pas-de-Calais and Dunkirk) over the past five centuries. It presents a selection of remarkable coastal floods that occurred in this area and integrates not only old events but also those occurring after the gauging period began. The information is structured around storms and coastal flooding summary sheets. Accompanied and supported by a historian, several research and field missions were carried out and a large number of archival sources explored and, whenever possible, exploited. The historical analysis began with the consultation of the documentary information stored in the rich library of the communal archive of Dunkirk, Gravelines, Calais and Saint-Omer. The most consulted documents were obtained directly from the municipal archives because the Municipal Acts guarantee a chronological continuity at least from the end of the 16th century up to the French Revolution (1789). Very useful for spotting extreme events, they unfortunately provide poor instrumental information. We therefore also considered data from local chronicles of annals of the city of Dunkirk, as well as reports written by scientists or naturalists to describe tides at Calais, Gravelines, Dunkirk, 
Nieuwpoort and Ostend. Most of them contain old maps, technical reports, sketches or plans of dykes, sluices and docks designed by engineers of the 18th to 20th centuries and from which it may be possible to estimate water levels reached during extreme events. Bibliographical documents are mostly chronicles, annals and memoirs written after the disaster. Finally, for the more recent period, available local newspapers were consulted.

Multiplying the sources and trying to cross-check events allowed us to constitute a database of 73 events. We focused the research on the period between 1500 and 1950, since most of the time tide gauge observations are available after 1950. The first event took place in 1507 and the last in 1995. Depending on how it is mentioned in the archive and as shown in Fig. 2a, the collated events were split in two groups. Storm surge events are events where there is a clear mention of flooding within the sources. Are considered as storms, events where only information about strong wind and gales are available. Except for the 19th century, we have many more storm surge events than storms events. All the collected events are summarized in Table 2.

\subsection{Data quality control}

First of all, it is appropriate to remember that the storm surge is the variable of interest in our historical research. It should, however, be stressed here that the total sea level, as it is a more operational information, is likely to be available most often. The conversion to the storm surge is performed afterwards by subtracting the predicted levels (which are calculated using the tide coefficients).

As mentioned earlier, archival documents are of different natures and qualities. We therefore decided to classify them by their degree of reliability according to a scale ranging between 1 and 4.

- Degree 1. Not very reliable historical source (it is impossible to indicate the exact documentary origin). It is particularly the case for $\mathrm{HI}$ found on the web.

- Degree 2. Information found in scientific books talking about storms without clearly mentioning the sources.

- Degree 3. Books, newspapers, reports and eyewitness statements citing historical events and clearly specifying its archival sources.

- Degree 4. The highest level of reliability. Information is taken from a primary source (e.g., an original archival report talking about a storm written by an engineer in the days following the event).

Although the information classified as a category 1 document is not very reliable, it still gives the information that something happened at a date and is therefore not outright and immediately ignored. Typically this type of document needs to be cross-checked with other documents. As shown in Fig. 2b, (a)

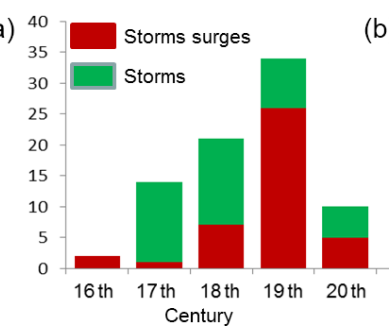

(b)

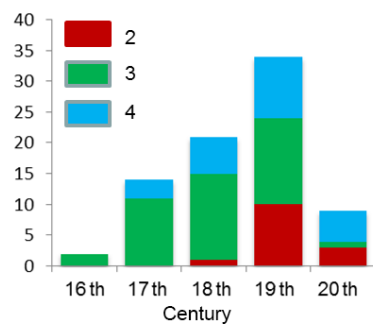

Figure 2. Distribution in time of the type of the events in the data base (a); quality of the data (b).

the classification of the data reveals a good reliability of collected information as there are no sources classified in category 1 and less than $10 \%$ of the sources are in category 2 . It is worth noting that paradoxically, the older the information, the more reliable the archival document is.

Some other data quality related issues must be dealt with especially when using old data and when to merge it with recent ones in a same inference: how to deal with old data uncertainties? How should the evolution of some physiographic parameters around the site of interest (bathymetry, topography, land cover, etc.) be dealt with? To what extent can we be sure that events which occurred hundreds of years ago are representative of the actual risk level?

All types of data indeed require quality control and need to be corrected and homogenized if necessary to ensure that they are reflecting real and natural variations of the studied phenomena rather than the influence of other factors. This is particularly the case for historical data that have been taken in different site conditions and have not been taken using modern standards and techniques (Brázdil et al., 2010). And finally, as mentioned in the introductory section, the use of old data improves the frequency estimation of extreme events significantly even if they are inaccurate. The objective of the present paper is then to collect the information and to quantify it in order to obtain approximate values of the variable of interest, without seeking accurate reconstructions.

\subsection{The historical surge dataset}

The concern is that it is not always possible to estimate a storm surge or a sea level from the information collected for each event. We focus herein on the reconstruction of some events of the 18th century (1720-1767) where certain HI makes it possible to estimate water levels. As depicted in Fig. 2a, out of the 73 events, 40 are identified as events causing coastal floods, but not all the sources contain quantitative data or at least some information about water level reached. We selected herein the events with the most information about some characteristics of the event (the water level reached, wind speed and direction and in some cases measured information). Table 3 shows a synthesis of the six events which we will analyze in more detail, showing the tide 
Table 2. Details of 1500-2015 Nord-Pas-de-Calais historical storms and storm surges sources.

\begin{tabular}{|c|c|c|c|c|}
\hline Year/date & $\begin{array}{l}\text { Data } \\
\text { type }\end{array}$ & $\begin{array}{l}\text { Quality } \\
\text { index }\end{array}$ & Source name & Observer occupation \\
\hline 1507 & Surge & 3 & Harrau (1901) & Historian \\
\hline 1 Nov 1570 & Surge & 3 & Faulconnier (1730) & Mayor of Dunkirk \\
\hline 1605 & Surge & 3 & Derode (1852) & Historian \\
\hline 12 Jan 1613 & Surge & 4 & MAS-O (18th century) - Jean Hendricq & Bourgeois and merchant of the city \\
\hline 1 Nov 1621 & Surge & 4 & & \\
\hline 3 Nov 1641 & Surge & 3 & Landrin (1888) & Archivist (Calais) \\
\hline 1644 & Surge & 4 & Lefebvre (1766) & Priest \\
\hline 1663 & Surge & 3 & Derode (1852) & Historian \\
\hline Dec 1663 & Surge & 3 & Baron C. de Warenghien (1924) & Historian \\
\hline 1665 & Surge & 3 & Derode (1852) & Historian \\
\hline 1671 & Surge & 3 & & \\
\hline 1675 & Surge & 3 & & \\
\hline 16 Feb 1699 & Surge & 3 & Harrau (1903) & Historian \\
\hline 1715 & Surge & 3 & Derode (1852) & Historian \\
\hline 1720 & Surge & 3 & & \\
\hline 31 Dec 1720 & Surge & 4 & De Lalande (1781) & Astronomer \\
\hline 25 Dec 1730 & Storm & 3 & Demotier (1856) & Local historian \\
\hline 1734 & Surge & 4 & MAD (AncDK15) & Unknown \\
\hline 19 Jan 1735 & Storm & 4 & & \\
\hline 27 Feb 1736 & Surge & 4 & MAD, (AncDK291)/Demotier (1856) & Historian \\
\hline 1 Oct 1744 & Storm & 3 & Le Tellier (1927) & Local of Dunkirk \\
\hline 11 Mar 1750 & Surge & 3 & De Lalande (1781) & Astronomer \\
\hline $6 \mathrm{Jul} 1760$ & Storm & 3 & Almache de Calais (1845) & Unknown \\
\hline 2 Dec 1763 & Surge & 3 & De Lalande (1781) & Astronomer \\
\hline 28 Sep 1764 & Surge & 2 & J. Goutier "Amis du Vieux Calais" & Unknown \\
\hline 2 Jan 1767 & Surge & 3 & Bossaut (1898) & Librarian \\
\hline May 1774 & Surge & 4 & MAD, ref. 2 Fi 169 & Unknown \\
\hline 1 Jan 1777 & Surge & 3 & de Bertrand (1855) & Writer \\
\hline 1 Jan 1778 & Storm & 3 & Moreel (1931) & Lawyer \\
\hline 31 Dec 1778 & Surge & 4 & Pigault de Lespinoy, 19th cent. - a & Mayor of Calais \\
\hline 2 Feb 1791 & Surge & 4 & Pigault de Lespinoy, 19th cent. - b & \\
\hline 17 Nov 1791 & Surge & 2 & Barron $(2007)$ & Journalist \\
\hline 4 Sep 1793 & Surge & 3 & Harrau (1898) & Historian \\
\hline 30 Oct 1795 & Storm & 3 & Landrin (1888) & Archivist (Calais) \\
\hline 13 Nov 1795 & Storm & 3 & Demotier (1856) & Historian \\
\hline 9 Nov 1800 & Storm & 4 & MAD, ref. 2Q9 & Unknown \\
\hline 29 Mar 1802 & Storm & 3 & Lemaire (1857) & Regent \\
\hline 3 Nov 1804 & Storm & 3 & Lemaire (1857) & Regent \\
\hline 1807 & Surge & 3 & Derode (1852) & Historian \\
\hline 18 Feb 1807 & Storm & 3 & Mannheim, 26 Jan 1808 & Newspaper \\
\hline \multirow[t]{2}{*}{2 Dec 1807} & Storm & 3 & Lemaire (1857) & Re Jan 1808 \\
\hline & Surge & 4 & MAC, "floods" sheets & Archivists (Dunkirk) \\
\hline 14 Nov 1810 & Storm & 2 & Gonsseaume (1988) & Historian \\
\hline 3 Jan 1825 & Surge & 2 & MAC, "storms" sheets & Archivists (Dunkirk) \\
\hline 4 Feb 1825 & Surge & 4 & MAD, ref. 506 & Harbor engineer \\
\hline 19 Oct 1825 & Storm & 4 & MAC, "storms" sheets & Archivists (Dunkirk) \\
\hline 29 Nov 1836 & Storm & 3 & Union Faulconnier (1912) & Mayor of Dunkirk \\
\hline 2 Jan 1846 & Surge & 3 & Derode (1852) & Historian \\
\hline 2 Oct 1846 & Surge & 3 & & \\
\hline 26 Sep 1853 & Storm & 3 & Zandyck (1861) & Military surgeon and physician \\
\hline 26 Oct 1859 & Storm & 3 & & \\
\hline 2 Nov 1859 & Storm & 3 & & \\
\hline 16 Jan 1867 & Storm & 2 & Gilles Peltier "Amis du Vieux Calais" & Unknown \\
\hline 2 Dec 1867 & Storm & 2 & Barron (2007) & Journalist \\
\hline 30 Jan 1877 & Storm & 4 & MAC, "storms" sheets & Archivists (Dunkirk) \\
\hline 21 Dec 1892 & Storm & 3 & Landrin (1888) & Archivist (Calais) \\
\hline
\end{tabular}


Table 2. Continued.

\begin{tabular}{lccll}
\hline Year/date & $\begin{array}{c}\text { Data } \\
\text { type }\end{array}$ & $\begin{array}{c}\text { Quality } \\
\text { index }\end{array}$ & Source name & Observer occupation \\
\hline 10 Jan 1893 & Storm & 4 & MAD, reference 5 S 1 & \\
18 Nov 1893 & Storm & 2 & Gilles Peltier “Amis du Vieux Calais” & Harbor Engineer \\
11 Oct 1896 & Storm & 2 & Gonsseaume (1988) & Historian \\
27 Jan 1897 & Storm & 2 & Gonsseaume (1988) & Historian \\
29 Nov 1897 & Surge & 4 & MAD, reference 4 S 874 & Architect \\
2 Mar 1898 & Storm & 4 & Le Gravelinois newspaper (1989) & Unknown \\
13 Jan 1899 & Storm & 4 & Le Nord Maritime newspaper (1899) & Unknown \\
10 Dec 1902 & Storm & 2 & Gonsseaume (1988) & Historian \\
11 Sep 1904 & Storm & 3 & Bouchet (1911) & Man of Letters \\
8 Jan 1928 & Storm & 2 & Gonsseaume (1988) & Historian \\
7 Dec 1929 & Storm & 2 & Gonsseaume (1988) & Historian \\
28 Nov 1932 & Storm & 4 & MAD, ref. 4 S 881 & City council of Dunkirk \\
1 Dec 1936 & Surge & 4 & & \\
1 Mar 1949 & Surge & 4 & La Voix du Nord newspaper (1949) & Unknown \\
1 Feb 1953 & Surge & 4 & La Voix du Nord newspaper (1953) & Unknown \\
16 Sep 1966 & Surge & 4 & La Voix du Nord newspaper (1966) & Unknown \\
2 Jan 1995 & Surge & 3 & Maspataud (2011) & PhD student \\
\hline
\end{tabular}

MAS-O: Saint-Omer Municipal Archives - Historical collection of Jean Hendricq bourgeois of Saint Omer; MAD: Dunkirk Municipal Archives; MAC: Calais Municipal Archives - thematic sheets.

coefficient (obtained from the SHOM website), some wind characteristics and water levels reached in Dunkirk and other cities. The tide coefficient is a ratio of the semi-diurnal amplitude by the mean spring neap tide amplitude introduced by Laplace in the 19th century and commonly used in France since then. Today, the coefficient 100 is attributed by definition to the semi-diurnal amplitude of equinox spring tides of Brest. Therefore, the range of the coefficient lies between 20 and 120, i.e., the lowest and highest astronomical tides. Calculated for each tide at Brest harbor, it is applied to the complete Metropolitan French Atlantic and Channel coastal zone (Simon, 2007). As with the short-term HI, a description of these events which are quite well documented in the literature is presented in Appendix B with a description of some other historical events (of which the available information did not allow an estimate of a storm surge value). Some other HI about other extreme storms, occurring in the period 17671897, were collected in the archives and identified as events causing coastal floods. A description of these events is also presented in Appendix B. To be able to reduce the CI of the high return levels (RLs) (the 1000-year one for instance), it is insufficient to have the time window (the historical period), as the observations or estimates of high surges are unknown. A fixed time window and magnitudes of the available high storm surges are required to improve the estimates of probabilities of failure. The exhaustiveness assumption of the HI on this time window will therefore be too crude and will make no sense. The historical period 1770-1897 was therefore eliminated from inference. Fortunately, these discontinuities in the historical period can be managed in the FM (Hamdi et al., 2015). Two non-successive time windows,
1720-1770 and 1897-2015, will therefore be used as historical periods in the inference.

The extreme storm surges that occurred during the 17201767 time window are then analyzed and the development of a methodology to estimate the surges induced by the events from the last part of the 18th and the 19th century is undergoing. Table 3 shows estimated water levels (for Dunkirk, Gravelines, Calais, Ostend and Nieuwpoort) compared to the associated Mean High-Water Springs (MHWS) which is the highest level reached by spring tides (on the average over a period of time often equal to 19 years). De Fourcroy de Ramecourt (1780) presented the water levels in "royal foot" of Paris, where 1 foot corresponds to $0.325 \mathrm{~m}$ and is divided into 12 inches $(1 \mathrm{inch}=0.027 \mathrm{~m})$ except for the Ostend levels that are given in the Flemish-Austrian foot (corresponding to $0.272 \mathrm{~m}$ and divided in 11 inches). As a first approach the height of the surge above the MHWS level was estimated, which has the advantage that the local reference level does not need to be transposed into the French leveling system and as the historic sea level is considered, there is no need to assess sea level rise, which due to climate change can be discarded. De Fourcroy de Ramecourt (1780) gave water levels for the following five cities in their respective leveling system: in Calais, zero corresponds to a fixed point on the Citadelle sluice; in Gravelines, zero corresponds to a fixed point on the sluice of the river Aa. For Dunkirk, the "likely low tide of mean spring tides" is considered as a zero point and marked on the docks of the Bergues sluice; we will subsequently refer to this zero as "Bergues Zero". The location of the measure point of the Bergues sluice is presented in Fig. 1b on an old map of Dunkirk city. The difference be- 
Table 3. HI about water levels in Dunkirk and other cities (unless otherwise stated, Heights are given in French royal foot which corresponds to $0.325 \mathrm{~m})$.

\begin{tabular}{|c|c|c|c|c|c|c|c|}
\hline $\begin{array}{l}\text { Date } \\
\text { and no. }\end{array}$ & $\begin{array}{r}\text { Tide } \\
\text { coefficient }^{\mathrm{a}}\end{array}$ & Characterics & $\begin{array}{l}\text { Wind } \\
\text { direction }\end{array}$ & City & $\begin{array}{l}\text { Water level } \\
\text { (ft) }\end{array}$ & $\begin{array}{l}\text { Surges above } \\
\text { MHWS (m) }\end{array}$ & Source name \\
\hline $\begin{array}{l}31 \text { Dec } 1720 \\
1\end{array}$ & $104-104$ & Violent storm & NW & Dunkirk & $22 \mathrm{ft} 3 \mathrm{in}^{\mathrm{b}}$ & - & $\begin{array}{l}\text { De Fourcroy de Ramecourt (1780); } \\
\text { Plocq (1873). }\end{array}$ \\
\hline $\begin{array}{l}27 \text { Feb } 1736 \\
2\end{array}$ & $110-114$ & $\begin{array}{l}\text { Accompanied by } \\
\text { strong winds }\end{array}$ & SW to $\mathrm{N}$ & $\begin{array}{l}\text { Gravelines } \\
\text { Calais }\end{array}$ & $\begin{array}{l}13 \mathrm{ft} 2 \text { in }^{\mathrm{b}} \\
>1767\end{array}$ & $\begin{array}{l}1.38 \\
1.06\end{array}$ & $\begin{array}{l}\text { De Lalande (1781); } \\
\text { De Fourcroy de Ramecourt (1780). }\end{array}$ \\
\hline $\begin{array}{l}11 \text { Mar } 1750 \\
3\end{array}$ & $115-111$ & $\begin{array}{l}\text { Generally } \\
\text { accompanied by } \\
\text { strong winds }\end{array}$ & $\mathrm{SW}$ to $\mathrm{N}$ & $\begin{array}{l}\text { Gravelines } \\
\text { Ostend }\end{array}$ & $\begin{array}{l}12 \mathrm{ft} 2 \text { in } \\
13 \mathrm{ft} \text { in }^{\mathrm{c}}\end{array}$ & $\begin{array}{c}1.05 \\
-\end{array}$ & $\begin{array}{l}\text { De Lalande (1781); } \\
\text { De Fourcroy de Ramecourt (1780); } \\
\text { Mann }(1777,1780) \text {. }\end{array}$ \\
\hline $\begin{array}{l}2 \text { Dec } 1763 \\
4\end{array}$ & $78-81$ & $\begin{array}{l}\text { Generally } \\
\text { accompanied by } \\
\text { strong winds }\end{array}$ & SSW to $\mathrm{N}$ & $\begin{array}{l}\text { Dunkirk } \\
\text { Calais } \\
\text { Gravelines } \\
\text { Ostend } \\
\text { Nieuwpoort }\end{array}$ & $\begin{array}{l}22 \mathrm{ft} \\
17 \mathrm{ft}^{2} \text { in } \\
14 \mathrm{ft}^{2} \text { in } \\
14 \mathrm{ft}^{\mathrm{c}} \\
14 \mathrm{ft}^{\mathrm{c}}\end{array}$ & $\begin{array}{c}\text { De Lalande (1781); } \\
- \\
0.57 \\
0.97 \\
1.10 \\
0.97\end{array}$ & $\begin{array}{l}\text { De Fourcroy de Ramecourt (1780); } \\
\text { Mann }(1777,1780)\end{array}$ \\
\hline $\begin{array}{l}2 \text { Jan } 1767 \\
5\end{array}$ & $93-96$ & Violent storm & $\begin{array}{l}\text { WNW- } \\
\text { NNW }\end{array}$ & $\begin{array}{l}\text { Dunkirk } \\
\text { Calais } \\
\text { Gravelines } \\
\text { Ostend } \\
\text { Nieuwpoort }\end{array}$ & $\begin{array}{l}22 \mathrm{ft} 6 \text { in } \\
18 \mathrm{ft} 8 \text { in } \\
15 \mathrm{ft} 10 \text { in } \mathrm{fft}^{\mathrm{c}} \\
17 \mathrm{ft}^{1} \text { in }^{\mathrm{c}}\end{array}$ & $\begin{array}{l}- \\
1.06 \\
1.51 \\
1.60 \\
1.94\end{array}$ & $\begin{array}{l}\text { Histoire de l'Académie } \\
\text { Royale des Sciences } \\
\text { (1767); } \\
\text { De Fourcroy de Ramecourt (1780); } \\
\text { Mann }(1777,1780)\end{array}$ \\
\hline $\begin{array}{l}1 \text { Dec } 1936 \\
6\end{array}$ & 99-96 & Violent storm & & Dunkirk & $1 \mathrm{~m}>$ pred & - & MAD 4S 881 \\
\hline
\end{tabular}

${ }^{a}$ Source: SHOM. ${ }^{b}$ Reconstructed water levels. ${ }^{c}$ Foot of Brussels $(1 \mathrm{ft}=0.273 \mathrm{~m})$.

tween the observed water levels and the MHWS is the surge above MHWS. The three levels are about the same height, ranging from 1.46 to $1.62 \mathrm{~m}$. We calculated the surge above MHWS for Calais, Gravelines, Nieuwpoort and Ostend; they are shown in the second-to-last column of Table 3. It is interesting to note that, for the 1763 and 1767 events, the highest levels were reconstructed in Ostend and the lowest levels in Calais.

For the sake of convenience and for more precision, we needed to transform the surges above MHWS presented in the second-to-last column of Table 3 into skew surges. This refinement required the development of a tide coefficientbased methodology. Indeed, the tide coefficient for each storm event indicates whether surge above MHWS is overor underrated or approximately correct. As this coefficient is calculated for the Brest site and applied to the whole coastal zone, a table showing expected mean levels in Dunkirk for each tide coefficient was established. One tide coefficient estimated at Brest can have different high water levels than those taken at Dunkirk. For this study, it was assumed that the historic MHWS corresponds to the tide coefficient 95. In the developed methodology, all the 2016 high tides for each tide coefficient are used and the water levels for each tide coefficient are averaged. The difference $\Delta_{\mathrm{WL}}$ between this averaged level and the water level corresponding to the tide co-
Table 4. Historical skew surges induced by the 1720-1767 events. Heights are given in metres.

\begin{tabular}{rrcrr}
\hline Date & $\begin{array}{r}\text { Tide } \\
\text { coeff. }\end{array}$ & $\begin{array}{r}\text { Surge } \\
\text { above } \\
\text { MHWS }\end{array}$ & $\Delta_{\text {WL }}$ & $\begin{array}{r}\text { Skew } \\
\text { surge }\end{array}$ \\
\hline 1720 & 104 & 1.54 & -0.17 & 1.37 \\
1763 & $78 / 81$ & 1.46 & $0.29 / 0.24$ & $1.75 / 1.7$ \\
1767 & 93 & 1.62 & 0.01 & 1.63 \\
\hline
\end{tabular}

efficient 95 (the actual MHWS) is then calculated and added (or subtracted) to the historic surge above MHWS. Where we have two surges, the mean of the two values is considered. Results for the Dunkirk surges are shown in the last column of Table 4.

In addition to the water levels reached during events and in specific years, other types of HI (lower bounds and ranges) can be collected. For instance, De Fourcroy de Ramecourt (1780) stated that the highest water level measured during the period 1720-1767 was the one induced by the 1767 extraordinary storm. Paradoxical though it may seem at first sight, the skew surge caused by the 1763 storm is greater than the 1767 one. A plausible explanation is that 


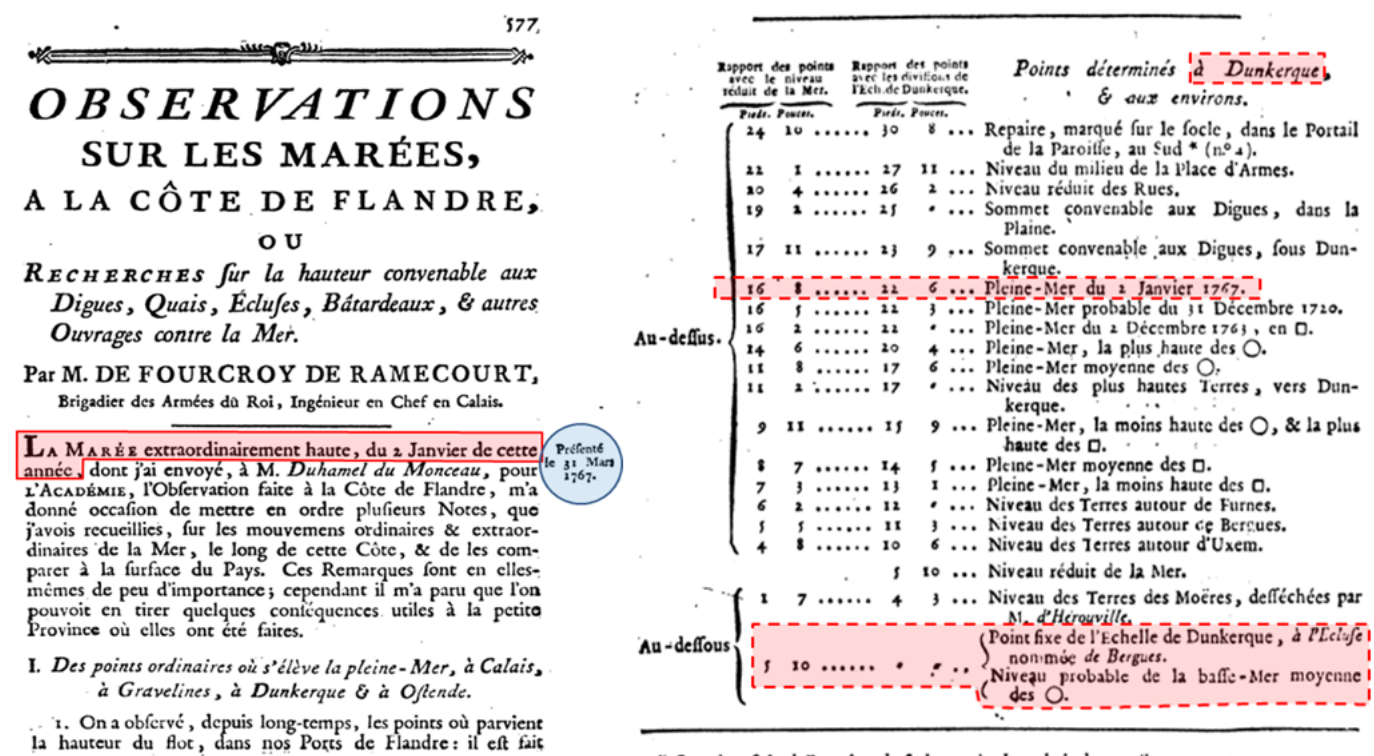

hauteur du flor, dans nos Ports de Flandre: il eft fais Tome VIII,

$a$

- Ce point eft le deffus même du focle, ou jambage dioit du portail, en entrant.

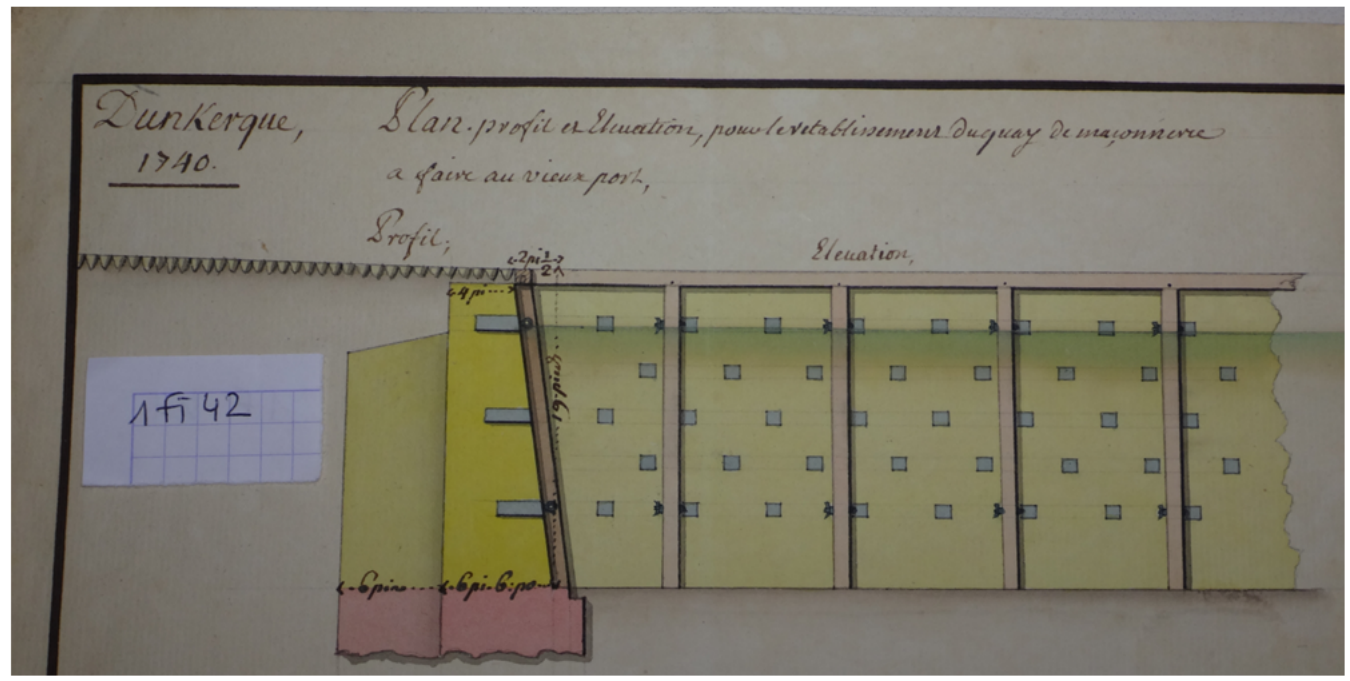

Figure 3. Two examples of HI as presented in the archives. Top panel: the 1767 extreme storm surge event in Dunkirk (De Fourcroy de Ramecourt, 1780); bottom panel: a profile of the Dunkirk harbor dock from the municipal archives of Dunkirk (ref. 1Fi42, 1740). Translation of the text highlighted in red is as follows: surcote de Pleine mer: skew surge; La marée extraordinairement haute, du 2 janvier de cette année: the tide was extraordinarily high this year on 2 January; Point fixe de l'Echelle de Dunkerque: fixed point of the Dunkirk scale; Niveau probable de la basse-Mer moyenne: probable level of the mean low water.

the 1767 event occurred when the tide was higher than that of 1763. Figure 3 shows two examples of HI collected in the archives.

For the Dunkirk series, it is interesting to see that it is easier to estimate storm surges induced by events from the 18th century, as the water levels were either measured or reconstructed only a few years after the events took place. During research for his thesis, Pouvreau (2008) started an inventory of existing tide gauge data available in different archive services in France. According to him, the first observations of the sea level in Dunkirk were made in 1701 and 1702 , where time and height were reported. Observations were also made in 1802 and another observation campaign was held during 1835 . The first longer series dates from 1865 to 1875 . For the 20th century, only sparse data is available for the first half of the century. Pouvreau (2008) only listed the data found in the archives of the National Geographic Institute (Institut Géographique National - IGN), the Marine Hydrographic and Oceanographic Service (Service Hydrographique et Océanographique de la Marine - SHOM) and the Historical Service of Defense (Service Historique de la Défense - SHD). During the present study we found ev- 
idence that sea levels were measured at the Bergues sluice during the 18th century and that various hydrographic campaigns were carried out during the 19th century (De Fourcroy de Ramecourt, 1780). This research and initial analysis of historical data shows the potential of the data collected, as we were able to quantify some historical skew surges, but it also shows how difficult and time-consuming the transformation of descriptive information into skew surge values is, and that more detailed analysis will be necessary to estimate the other historical surges. It was concluded that all historic surges appear to be almost at least as high as the highest systematic surge. In response to the specific question "what could impact the variable of interest throughout the whole historical period?", old and recent data were then compared. For example, the reconstructed skew surges were compared to the systematic ones. The reconstructed skew surge heights obtained from the tide gauge data, the quantified surges from the literature and the reconstructed values from this study were also compared, as the hypothesis is made that water levels measured at the tide gauge and the different locations of Dunkirk harbor are comparable. At this point we are not able to conclude on the evolution of the tides throughout the centuries. Historic tide gauge data from cities in the north of France is currently being digitized and reconstructed at the French Oceanographic Service (SHOM - Service Hydrographique et Océanographique de la Marine) and University of Côte d'Opale (Latapy et al., 2017). Further, it is worth noting that the current tide gauge is situated at the entrance of the harbor. The predicted water levels may differ within the inner harbor area, where the reconstructed surges were estimated. Hydrodynamic modeling could help estimate the difference between water levels at the entrance of the harbor area (Bulteau et al., 2015).

\section{Frequency estimation of extreme storm surges using HI}

In this work, we suggest a method of incorporating the HI developed by Hamdi et al. (2015). The proposed FM (POTH) is based on the Peaks-Over-Threshold model using HI. The POTH method uses two types of HI: over-threshold supplementary (OTS) and historical maxima $\left(H_{\mathrm{Max}}\right)$ data which are structured in historical periods. Both kinds of historical data can only be complementary to the main systematic sample. The POTH FM was applied to the Dunkirk site to assess the value of historical data in characterizing the coastal flooding hazard and more particularly in improving the frequency estimation of extreme storm surges.

\subsection{Settings of the POT frequency model}

To prepare the systematic POT sample and in order to exploit all available data separated by gaps, the surges recorded since 1956 were concatenated to form one systematic series.
However, it makes for subjectivity in what should be taken as a reasonable threshold for the POT frequency model. Indeed, the use of a threshold that is too low can introduce a bias in the estimation by using observations which may not be extreme data, which violates the principle of the extreme value theory. On the other hand, the use of a too-high threshold will reduce the sample of extreme data. Coles (2001) has shown that stability plots constitute a graphical tool for selecting the optimal value of the threshold. The stability plots are the estimates of the GPD parameters and the mean residual life-plot as a function of the threshold when using the POT approach. It was concluded that a POT threshold equal to $0.75 \mathrm{~m}$ (corresponding to a rate of events equal to 1.4 events per year) is an adequate choice. The POT sample with an effective duration $w_{\mathrm{s}}$ of 46.5 years (from 1956 to 2015) is represented by the grey bars in Fig. 4a, c and e. As homogeneity, stationarity and randomness of time series are prerequisites in a FA (Rao and Hamed, 2001), non-parametric tests such as the Wilcoxon test for homogeneity (Wilcoxon, 1945), the Kendall test for stationarity (Mann, 1945), and the Wald-Wolfowitz test for randomness (Wald and Wolfowitz, 1943) are applied. These tests were passed by the Dunkirk station at the $5 \%$ level of significance.

\subsection{The POTH frequency model}

The HI is used in the present paper as $H_{\text {Max }}$ data. A $H_{\mathrm{Max}}$ data period corresponds to a time interval of known duration $w_{H_{\mathrm{Max}}}$ during which historical $n_{k}$-largest values are available. Periods are assumed to be potentially disjointed from the systematic period. The distribution of the $H_{\mathrm{Max}}$ exceedances is assumed to be a Generalized Pareto one (GPD). The observed distribution function of $H_{\mathrm{Max}}$ and systematic data are constructed in the same way with the Weibull rule. To estimate the distribution parameters by using the maximum likelihood technique in the POTH model, let us assume a set of POT systematic observations $X_{\text {sys }, i}$ with a set of historical $H_{\mathrm{Max}}$ surges $X_{H_{\mathrm{Max}}, i}$ and assume that the systematic and historical storm surges are available with a density function $f_{X}($.$) . Under the assumption that the surges are$ independent and identically distributed, the global likelihood function of the whole data sample is any function $L\left(G \mid \theta_{\leftrightarrow}\right)$ proportional to the joint probability density function $f_{X}($.) evaluated at the observed sample and it is the product of the likelihood functions of the particular types of events and information. The global log-likelihood can be expressed as

$\ell\left(G \mid \theta_{\leftrightarrow}\right)=\overbrace{\ell\left(X_{\text {sys }, i} \mid \theta\right)}^{\text {systematic data }}+\overbrace{\ell\left(X_{H \text { Max }, i} \mid \theta\right)}^{H_{\text {Max }} \text { data }}$.

Let us assume a set of $n$ POT systematic observations $X_{i}$ and a selected threshold $u_{\mathrm{s}}$ and consider $w_{\mathrm{s}}$ the total duration. For a homogeneous Poisson process with rate $\lambda$, the 

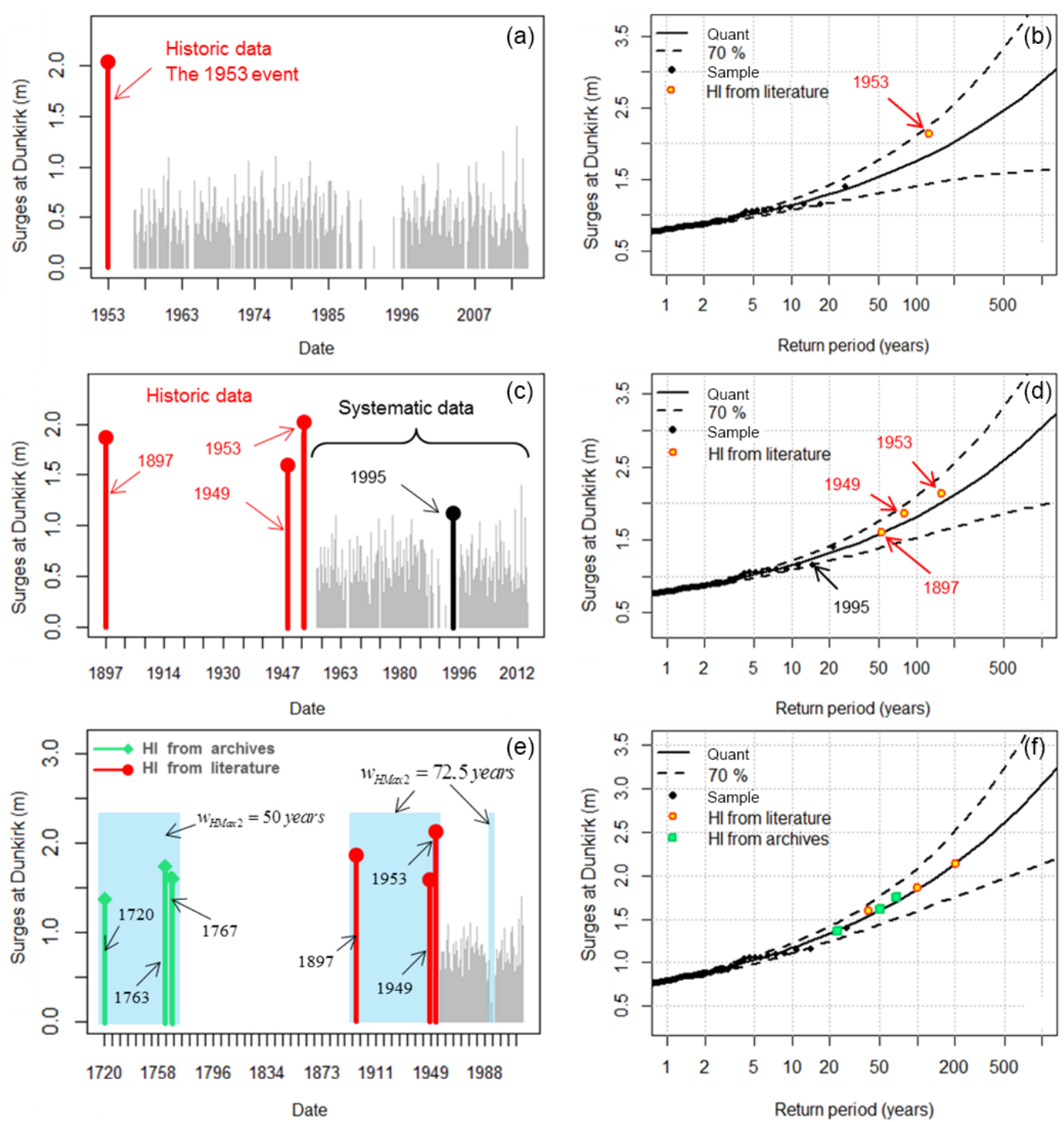

Figure 4. The GPD fitted to the POTH surges in Dunkirk: (a, b) the 1953 event as historical data; (c, d) with historical data from literature and $(\mathbf{e}, \mathbf{f})$ with historical data from literature and archives. The 1995 event is considered as systematic.

$\log$-likelihood $\ell\left(X_{\mathrm{sys}, i} \mid \theta\right)$ is

$$
\begin{aligned}
\ell\left(X_{\mathrm{sys}, i} \mid \theta\right) & =n \log \left(\lambda w_{\mathrm{s}}\right)-\log (n !)-\lambda w_{\mathrm{s}} \\
& +\sum_{i=1}^{n} \log f\left(X_{\mathrm{sys}, i}, \theta\right) .
\end{aligned}
$$

For the $H_{\text {Max }}$ data, it takes the form

$$
\begin{aligned}
\ell\left(X_{\left.H_{\mathrm{Max}, i} \mid \theta\right)}=n_{k} \log \left(\lambda w_{H_{\mathrm{Max}}}\right)-\lambda w_{H_{\mathrm{Max}}}\left[1-F\left(X_{k}, \theta\right)\right]\right. \\
+\sum_{i=1}^{n_{k}} \log f\left(X_{H_{\mathrm{Max}}, i}, \theta\right) .
\end{aligned}
$$

The reader is referred to Hamdi et al. (2015) for more details about each term of these expressions.

\subsection{Settings of the frequency model with HI (POTH)}

An important question arises in regard to the exhaustiveness of the HI collected in a well-defined time window (called herein the historical period). In order to properly perform the FA, this criterion must be fulfilled. Indeed, we have good evidence to believe that other than the 1995 storm surge, the surges induced by the 1897,1949 and 1953 storms are the biggest for the period 1897-2015. The POTH FM was first applied with a single historical datum, which is that of 1953 , represented by the red bar in Fig. 4a. It not complicated to demonstrate that this event is undoubtedly an outlier. Indeed, in order to detect outliers, the Grubbs-Beck test was used (Grubbs and Beck, 1972). As mentioned in the previous section, some historical extreme events experienced by Dunkirk 
city are available in the literature. Only this information (including the 1953 event) is considered in this first part of the case study.

Otherwise, HI is most often considered in the FA models for pre-gauging data. Little or no attention has been given to non-recorded extreme events that occurred during the systematic missing periods. As mentioned earlier in this paper, the sea level measurement induced by the 1995 storm was missed and a value of the skew surge $(1.15 \mathrm{~m})$ was reconstructed from information found in the literature (Maspataud, 2011). As this event is of ordinary intensity and has taken place very recently, it is considered as systematic data even if this type of data can be managed by the POTH FM by considering it as HI (Hamdi et al., 2015). The HI collected from both literature and archives with some model settings are summarized in Table 5 and the POTH sample with a historical period of 72.51 years is presented in Fig. 4b. Parameters characterizing datasets including both systematic and HI were introduced in Hamdi et al. (2015). The HI is used herein as $H_{\text {Max }}$ data that complements the systematic record (with an effective duration $D_{\text {eff }}$ equal to $w_{\mathrm{s}}$ ) on one historical period (1897-2015) with a known duration $w_{\mathrm{h}}=w_{H_{\mathrm{Max}}}=$ $2015-1897+1-D_{\text {eff }}\left(w_{\mathrm{h}}=72.51\right.$ years $)$ and three different historical data $\left(n_{k}=3\right)$. Other features of the POTH FM have been used. A parametric method (based on the Maximum Likelihood) for estimating the Generalized Pareto Distribution (GPD) parameters considering both systematic and historical data have been developed and used. The maximum likelihood method was selected for its statistical features, especially for large series and for the ease with which any additional information (i.e., the HI) is incorporated in it. On the other hand, the plotting positions exceedance formula based on both systematic observations and HI (Hirsch, 1987; Hirsch and Stedinger, 1987; Guo, 1990) is proposed to calculate the observed probabilities and has been incorporated into the POTH FM considered herein. For systematic data, there are several formulas that can be used to calculate the observed probabilities. Based on several studies (e.g., Alam and Matin, 2005; Makkonen, 2006), the Weibull plotting position rule was used herein $\left(p_{\mathrm{emp}}=i /(n+1)\right)$. The reader is referred to Hamdi et al. (2015) for more theoretical details on the POTH model and on the Renext package used to perform all the estimations and fits.

\section{Results and discussion}

We report herein the results of the FA applied to the Dunkirk tide gauge. As with any sensitive facility, high return levels (RLs) $(100,500$ and 1000-year extreme surges, for instance) are needed for the safety of NPPs. The results are presented in the form of probability plots in the right panel of Fig. 4d-f. The theoretical distribution function is represented by the solid line in this figure, while the dashed lines represent the limits of the $70 \%$ CIs. The HI is depicted by the empty red circles, while the black full ones represent the systematic sample. The results (estimates of the desired RLs and uncertainty parameters) are also summarized in Table 6. Fitting the GPD to the sample of extreme POTH storm surges yields the relative widths $\Delta \mathrm{CI} / S_{T}$ of the $70 \%$ CIs (the variance of the RL estimates are calculated with the delta method).

The FA was firstly performed considering systematic surges and the 1953 storm surge as historical data. It can be seen that the fit of the POTH sample including the 1953 historical event (with $w_{\mathrm{h}}$ equal to 16.5 years) presented in Fig. 4d (called hereafter the initial fitting), is poor at the right tail and more specifically, at the largest storm surge (the historical data of $2.13 \mathrm{~m}$ occurred in 1953) which have a much lower observed return period than its estimated one. The estimates of the RLs of interest and uncertainty parameters (the relative width $\Delta \mathrm{CI} / S_{T}$ of the $70 \% \mathrm{CIs}$ ) are presented in columns 2-3 of Table 6 . These initial findings are an important benchmark as we follow the evolution of the results to evaluate the impact of additional HI. 100-, 500- and 1000-year quantiles given by the POTH FM with the 1897, 1949 and 1953 historical storm surges included are about $3 \%-6 \%$ higher than those obtained by the initial POTH FM. This result was expected as the additional historical surges are higher than all the systematic ones. The relative widths of the CIs are about $20 \%-25 \%$ narrower.

Unlike the 1897 historical event, the 1949 and 1953 ones have a lower observed return period than their estimated one. A plausible explanation for this result is that the body of the distribution is better fitted than the right tail one and this is a shortcoming directly related to the exhaustiveness assumption used in the POTH FM. Indeed, as stated in Hamdi et al. (2015) and as mentioned above, a major limitation of the developed FM arises when the assumption related to the exhaustiveness of the information is not satisfied. This is obviously worrying for us because the POTH FM is based on this assumption. Overall, using additional data in the local FM has improved the variances associated with the estimation of the GPD parameters but did not conduct robust estimates with a better fitting (particularly at the right tail, the high RLs being very sensitive to the historical values) if the assumption of exhaustiveness is still strong. This first conclusion is likewise graphically backed by the CIs plots shown in Fig. 4e. Nevertheless, as the impact of historical data becomes more significant, there is an urgent need to carry out a deeper investigation of all the historical events that occurred in the region of interest (Nord-Pas-de-Calais) over the longest possible historical period. In order to have robust estimates and reduced uncertainties, it is absolutely necessary that the collected information be as complete as possible.

The robustness of the POTH FM is one of the more significant issues we must deal with. The main focus of this discussion is the assessment of the impact of the additional HI (collected from the archives) on the frequency estimates for high RLs. The same FM was performed but with the long- 
Table 5. The HI dataset (from literature and archives). Surges are given in $\mathrm{m}$ and $w_{H_{\mathrm{Max}}}$ and $w_{\mathrm{s}}$ in years.

\begin{tabular}{|c|c|c|c|c|c|c|c|}
\hline Year & 1720 & 1763 & 1767 & \multirow{2}{*}{$\begin{array}{l}\text { Events exist }\left(n_{k} \neq 0\right) \text { but } \\
\text { cannot be estimated }\end{array}$} & 1897 & 1949 & 1953 \\
\hline \multirow[t]{2}{*}{ Surge (m) } & 1.37 & 1.75 & 1.63 & & 1.86 & 1.60 & 2.13 \\
\hline & \multicolumn{3}{|c|}{$\begin{array}{l}- \text { HI from archives, } n_{k}=3 \\
-1720-1770 \text { time window } \\
-w_{H_{\text {Max } 1}}=50\end{array}$} & $\begin{array}{l}\text { - HI from archives, } n_{k} \neq 0 \\
-1770-1897 \text { time-window } \\
\text { - Not used in the inference }\end{array}$ & \multicolumn{3}{|c|}{$\begin{array}{l}- \text { HI from literature, } n_{k}=3 \\
-1897-2015 \text { time window } \\
-w_{H_{\mathrm{Max} 2}}=72.5 ; w_{\mathrm{s}}=46.5\end{array}$} \\
\hline
\end{tabular}

Table 6. The $T$-year quantiles and relative widths of their $70 \% \mathrm{CI}$ (all of the durations are given in years).

\begin{tabular}{|c|c|c|c|c|c|c|}
\hline \multirow{3}{*}{$\begin{array}{l}T \\
\text { (years) }\end{array}$} & \multicolumn{2}{|c|}{+1953 event } & \multicolumn{2}{|c|}{ + literature HI } & \multicolumn{2}{|c|}{+ literature $\&$ archives $\mathrm{HI}$} \\
\hline & \multirow{2}{*}{\multicolumn{2}{|c|}{$\begin{array}{l}w_{H_{\mathrm{Max} 1}}=16.5 \\
S_{T} \Delta \mathrm{CI} / S_{T}\end{array}$}} & \multicolumn{2}{|c|}{$w_{H_{\mathrm{Max}}}=72.5$} & \multirow{2}{*}{$\begin{array}{c}w_{H_{\mathrm{Max} 1}}=50 ; \\
S_{T}\end{array}$} & \multirow{2}{*}{$\begin{array}{c}w_{H_{\mathrm{Max} 2}}=72.5 \\
\Delta \mathrm{CI} / S_{T}\end{array}$} \\
\hline & & & $S_{T}$ & $\Delta \mathrm{CI} / S_{T}$ & & \\
\hline 100 & 1.76 & $40 \%$ & 1.82 & $32 \%$ & 1.84 & $26 \%$ \\
\hline 500 & 2.46 & $71 \%$ & 2.59 & $56 \%$ & 2.61 & $48 \%$ \\
\hline 1000 & 2.86 & $86 \%$ & 3.03 & $69 \%$ & 3.05 & $59 \%$ \\
\hline
\end{tabular}

term additional $\mathrm{HI}$ (collected in the archives) and different settings (Table 5). The results of the POTH FM using $\mathrm{HI}$ from both literature and archives (called hereafter the full FM) are likewise summarized in the last two columns of Table 6. The results are also presented in the form of a probability plot (Fig. 4f). Figure 7 consists of two subplots related to the FA of the Dunkirk extreme surges. The left side (Fig. 4c) shows collected data: the systematic surges are represented by the grey bars, the historical surges extracted from the literature by red bars and those extracted from the archives (estimated and corrected with regards to the tide coefficients) are represented by the green ones. We can also see the two time windows (the blue background areas in the graph), 1720-1770 and 1897-2015, used in the POTH FM as historical periods. The right side shows the results of the full FM. As mentioned earlier in this paper, to consider the full POTH FM, six historical storm surges distributed equally $\left(n_{k}=3\right)$ over two non-successive time windows: 1720-1770 $\left(w_{H_{\text {Max } 1}}=50\right.$ years $)$ and $1897-2015\left(w_{H_{\text {Max } 2}}=72.5\right.$ years, knowing that $w_{\mathrm{s}}=46.5$ years) are used as historical data. In the plotting positions, the archival historical surges are represented by green squares, while those found in the literature are depicted by red circles. The fitting presented in Fig. $4 \mathrm{f}$ shows a good adequacy between the plotting positions and theoretical distribution function (calculated probabilities of failure). Indeed, all the points of the observed distribution are not only inside the CI, but even better, they are almost on the theoretical distribution curve. Table 6 shows the following results.

- The RLs of interest had increased by only 10 to $20 \mathrm{~cm}$. This is an important element of robustness. Indeed, adding or removing one or more extreme values from the dataset does not significantly affect the desired RLs. In other words, it is important that the developed model is not very sensitive (in terms of RLs used as design bases) to a modification in the data regarding very few events. As a matter of fact, the model owes this robustness to the exhaustiveness of the available information.

- The relative widths of CIs with no archival HI included are 1.5 times larger than those given by the full model. This means that the user of the developed model is more confident in the estimations when using the additional HI collected in the archives.

After collecting $\mathrm{HI}$ about the most extreme storm surge events in the 18th and 20th centuries, it was first found that the 1953 event is still the most important one in terms of magnitude. The developed POTH FM attributed a 200-year return period to this event. The value of the surge induced by the 1953 storm is between 1.75 and $2.50 \mathrm{~m}$. That said, it is interesting to note that this CI includes the value of $2.40 \mathrm{~m}$ estimated by Le Gorgeu and Guitonneau (1954). This may be a reason to think that the continuation of our work on the quantification of the skew surges that occurred in the 19th century will perhaps reveal extreme surges similar to that induced by the 1953 storm.

\section{Conclusion and perspectives}

To improve the estimation of risk associated with exceptional high surges, HI about storms and coastal flooding events for the Nord-Pas-de-Calais was collected by historians for the 1500-1950 period. Qualitative and quantitative information about all the extreme storms that hit the region of interest were extracted from a large number of archival sources. In this paper, we presented the case study of Dunkirk in which the exceptional surge induced by the 1953 violent storm appears as an outlier. In a second step, the information collected 
(in both literature and archives) was examined. Quality control and cross-validation of the collected information indicate that our list of historic storms is complete as regards extreme storms. Only events that occurred in the periods $1720-1770$ and 1897-2015 were estimated and used in the POTH FM as historical data. To illustrate challenges and opportunities for using this additional data and analyzing extremes over a longer period than was previously possible, the results of the FA of extreme surges was presented and analyzed. The assessment of the impact of additional $\mathrm{HI}$ is carried out by comparing theoretical quantiles and associated confidence intervals, with and without archival historical data, and constitutes the main result of this paper.

The conclusions drawn in previous studies were examined in greater depth in the present paper. Indeed, on the basis of the results obtained previously (Hamdi et al., 2015) and in the present paper, the following conclusions are reached:

- the use of additional HI over longer periods than the gauging one can significantly improve the probabilistic and statistical treatment of a dataset containing an exceptional observation considered as an outlier (i.e., the 1953 storm surge);

- as the HI collected in both literature and archives tend to be extreme, the right-tail distribution has been reinforced and the 1953 "exceptional" event does not appear as an outlier any more;
- and as this additional information is exhaustive (relative to the corresponding historical periods), the RLs of interest increased very slightly and the confidence intervals were reduced significantly.

An in-depth study could help to thoroughly improve the quantification method of the historical surges and apply the developed model on other sites of interest. Finally, an attempt to carry out the estimation of the surges induced by the events from 1767 to the end of the 19th century is ongoing at the time of writing.

Data availability. Storm surges and water levels estimated from historical information are presented in this paper. Unfortunately, data as they were presented in archives and primary sources (the original information) cannot be published herein because the sources are confidential. 


\section{Appendix A: HI collected in the literature}

\section{A1 1 March 1949}

A violent storm with mean hourly wind speeds reaching almost $30 \mathrm{~m} \mathrm{~s}^{-1}$ and gusts of up to $38.5 \mathrm{~m} \mathrm{~s}^{-1}$ (Volker, 1953) was the cause of a storm surge that reached the coast of northern France and Belgium at the beginning of March 1949. The tide gauge of Antwerp in the Escaut estuary measured a water level higher than $7 \mathrm{~m}$ Tweede Algemene Waterpasing (TAW, a Belgian chart datum for which the 0 corresponds to the mean water level during low tide at Oostende Harbor) which classifies this event as a buitengewone stormvloed, an extraordinary storm surge (Codde and De Keyser, 1967). For the Dunkirk area two sources reporting water levels were found: the first saying that $7.30 \mathrm{~m}$ was reached as a maximum water level at the eastern dyke in Dunkirk, exceeding the predicted high tide, i.e., $5.70 \mathrm{~m}$, with $1.60 \mathrm{~m}$ (Le Gorgeu and Guittoneau, 1954). A second document relates that the maximum water level reached was about $7.55 \mathrm{~m}$ at Maloles-Bains, which would mean a surge of $1.85 \mathrm{~m}$ (DREAL Nord-Pas-de-Calais, 2017). It is worth noting that the use of proxy data (i.e., the descriptions of events in the historical sources summarized in Table 1) to extract sea-level values and to create storm-surge databases is seriously limited. For the 1791 and 1808 storms, there is sufficient evidence that extreme surge events took place (extreme water level on Walcheren Island) but the sources are not informative enough to estimate water levels reached in Dunkirk. A surge of $1.25 \mathrm{~m}$ is given for the storm of 1921 . The problem is that the type of surge (instantaneous or skew), the exact location at which it was recorded and the hydro-meteorological parameters are not reported. For the skew surge of 1949, two different values at two locations are given. There are predicted and observed water levels for the storms of 1905 and 1953 in Calais, which indicate that the difference is a skew surge, but likewise neither the exact location nor the information about the reference level are furnished. The need for tracing back to "direct data" describing a storm and its consequences becomes clear, as well as performing a cross-check of the data on a spatial and factual level, as Brazdil (2000) also suggests.

\section{A2 28 November 1897}

What was felt as stormy winds in Ireland on 27 November 1897 became an eastward-moving storm with gale-force winds over Great Britain, Denmark and Norway (Lamb, 1991). This storm caused interruption of telephone communications between the cities of Calais, Dunkirk and Lille and great damage to the coastal areas (Le Stéphanois, 30 November 1897). At Malo-les-Bains, a small town close to Dunkirk, the highest water level reached $7.36 \mathrm{~m}$, although the high tide was predicted at $5.50 \mathrm{~m}$, resulting in a skew surge of $1.86 \mathrm{~m}$ that caused huge damage to the port infrastructures (DREAL Nord-Pas-de-Calais, 2017).

\section{A3 14 January 1808}

During the night from 14 to 15 January 1808 , “a terrible storm, similar to a storm that hit the region less than a year before on February 18, 1807" hit the coasts of the most northern parts of France up to the Netherlands. This storm caused severe flooding in the Dunkirk area as well as in the Zeeland area in the southwestern parts of the Netherlands where the water rose up to 25 feet on the isle of Walcheren (i.e., $7.62 \mathrm{~m}$ ). The journal also reports more than 200 deaths. For the Dunkirk area, the last time the water levels rose as high as in January 1808 was 2 February 1791. Unfortunately, this source does not provide any information that we can quantify or any information on the meteorological and weather conditions that we can use to reconstruct the storm surge value.

\section{Appendix B: HI collected in the archives}

\section{B1 $\quad \mathbf{1 7 2 0 - 1 7 6 7}$}

In essays written by a mathematician of the French Royal Academy of Science, De Froucroy de Ramecourt (1780), who describes the tide phenomenon on the Flemish coast, some extreme water levels observed within the study area are reported and described. The author refers to five events that occurred during the period 1720 to 1767 . The same information is confirmed by a Flemish scientist, Dom Mann (1777, 1780). De Froucroy de Ramecourt (1780) witnessed the water levels induced by the 1763 and 1767 storms and reconstructed the level induced by the 1720 event in Dunkirk. Water levels at that time are given for the cities of Dunkirk, Gravelines and Calais in the pied du roi unit ("foot of the king" was a French measuring unit, corresponding to $0.325 \mathrm{~m}$ ) above local mean low-water springs. The French water levels are completed by measurements made in Flemish-Austrian feet (1 Flemish-Austrian foot is equal to $0.272 \mathrm{~m}$ ) above the highest astronomical tides for the cities of Ostend and Nieuwpoort (De Fourcroy de Ramecourt, 1780; Mann, 1777, 1780). The upper panel of Fig. 3 shows an example of $\mathrm{HI}$ as presented in the archives (De Fourcroy de Ramecourt, 1780).

The 1720 event is a memorable event for the city of Dunkirk, as the water level during spring tide was increased by the strong gales blowing from northwestern direction which destroyed the cofferdam built by the British in 1714, cutting the old harbor off from sea access and prohibiting any maritime trade, thus slowly causing the ruin of the city. The socio-cultural impact of the natural destruction of the cofferdam was huge, as it restarted trading in the city (Chambre de Commerce de Dunkerque, 1895; Plocq, 1873; de Belidor, 1788). In 1736, the only sea level available is given for Gravelines harbor, but extreme water levels are confirmed in the sources as they mention at least 4 feet (French unit "foot 
of the king" corresponding to $0.325 \mathrm{~m}$ ) of water in a district of Calais, and water levels that overtopped the docks of the harbor in Dunkirk (Municipal Archive of Dunkirk DK291, Demotier, 1856). As mentioned above, communal and municipal archives contain plans of dykes, docks and sluices in Dunkirk harbor designed by engineers with the means available at that time, and such sketches were recovered. A 1740 sketch showing a profile of the Dunkirk harbor dock is presented in the lower panel of Fig. 3 for illustrative purposes only. The use of these plans and sketches in the estimation of some historical storm surges is ongoing. The lower-lying streets of Gravelines were accidentally flooded by the high water levels in March 1750. The fact that an extreme water level was also reported in Ostend for the same day confirms the regional aspect of the event. The surge of $1763 \mathrm{oc}-$ curred in a period with mean tidal range, but water levels exceeded the level of mean spring high tide in Dunkirk, Calais and Ostend. Unfortunately, no more information about the flooded area is available. Strong west-northwesterly winds caused by a quick drop in pressure produced high water levels from Calais up to the Flemish cities. It is, at least for the period from 1720 to 1767 , the highest water level ever seen and known. The 1720 and 1767 events show good evidence of the wind direction and wind intensity, while in various sources, except for the water levels reported, the events from 1736, 1750 and 1763 are always cited together and described as "extraordinary sea levels that are accompanied or caused by strong winds blowing from southwest to north" (De Lalande, 1781; De Fourcroy de Ramecourt, 1780; Mann, 1777, 1780). As with the 1897-2015 historical/systematic periods, the same question related to the exhaustiveness of the HI collected in the 1720-1770 historical period arises. As our historical research on extreme storm surges occurred in this time window was very thorough, we have good reason to believe that the surges induced by the 1720,1763 and 1767 storms are the biggest for that historical period.

\section{B2 1767-1897}

For the 1778, 1791, 1808 and 1825 events, the sources clearly report that winds were blowing from northwesterly directions and that in Dunkirk the quays and docks of the harbor were overtopped as the highest water levels were reached. We know that, after the event of February 1825, at least 19 storm events occurred and we have good evidence to believe that some of them induced extreme surges, but either the information available is not sufficient to draw an approximate value of the water level, or the quantification of the storm surges induced by these events is complicated and time-consuming.

\section{B3 1936}

The 1936 event can be considered as a lower bound, as the document from the archive testifies that the "water level was at least $1 \mathrm{~m}$ higher than the predicted tide" during the storm that occurred on the night of 1 December 1936 (Municipal Archives of Dunkirk 4S 881). The 1936 event, which can be described as a moderately extreme storm, is the only one collected over the 50-year time window (1897-1949). As the surge lower bound value induced by this event is too small (i.e., exceeded more than 10 times during the systematic period), it could be exceeded several times during the 1897 1949 period. Its involvement in the statistical inference will have the opposite effect and will not only increase the width of the CI but will also degrade the quality of the fit. The 1936 historical event was therefore eliminated from inference. 
Competing interests. The authors declare that they have no conflicts of interest.

Acknowledgements. The authors thank the municipal archives of Dunkirk and Gravelines for their support during the collection of historical information.

Edited by: Ira Didenkulova

Reviewed by: three anonymous referees

\section{References}

Alam, M. J. B. and Matin, A.: Study of plotting position formulae for Surma basin inBangladesh, J. Civ. Eng., 33, 9-17, 2005.

Almache de Calais: Société d'Agriculture du Commerce Sciences et Arts de Calais, Almanach de la Ville et du Canton de Calais pour 1845, Calais: Imprimerie de D le Roy, 1845.

Baart, F., Bakker, M. A. J., Van Dongeren, A., den Heijer, C., Van Heteren, S., Smit, M. W. J., Van Koningsveld, M., and Pool, A.: Using 18th century storm-surge data from the Dutch Coast to improve the confindence in flood-risk estimate, Nat. Hazards Earth Syst. Sci., 11, 2791-2801, https://doi.org/10.5194/nhess11-2791-2011, 2011.

Bardet, L., Duluc, C.-M., Rebour, V., and L'Her, J.: Regional frequency analysis of extreme storm surges along the French coast, Nat. Hazards Earth Syst. Sci., 11, 1627-1639, https://doi.org/10.5194/nhess-11-1627-2011, 2011.

Baron C. de Warenghien: Extrait des Actes de la Société, in Bulletin Union Faulconnier, société historique de Dunkerque Tome XXI, Union Faulconnier, Dunkerque, 437-463, 1924.

Barron, B.: Appareillage immédiat, Editions du Camp du Drap d'Or, 2007.

Bossaut, M. A.: Le Portrait de Dunkerque après le Traité d'Utrecht, Mémoires de la Société Dunkerquoise pour l'Encouragement des Sciences, des Lettres et des Arts XXXe Volume, Dunkerque, Imprimerie Dunkerquoise, 1898.

Bouchet, E.: Histoire Populaire de Dunkerque au Moyen-Age, in: Bulletin Union Faulconnier, société historique de Dunkerque Tome XIV, Union Faulconnier, Dunkerque, 243-319, 1911.

Brazdil, R.: Historical Climatology: Definition, Data, Methods, Results, Geografický Časopis, 52, 99-121, 2000.

Brázdil, R., Dobrovolný, P., Luterbacher, J., Moberg, A., Pfister, C., Wheeler, D., and Zorita, E., European climate of the past 500 years: new challenges for historical climatology, Climatic Change, 101, 7-40, https://doi.org/10.1007/s10584-009-9783-z, 2010.

Bulteau, T., Idier, D., Lambert, J., and Garcin, M.: How historical information can improve estimation and prediction of extreme coastal water levels: application to the Xynthia event at La Rochelle (France), Nat. Hazards Earth Syst. Sci., 15, 1135-1147, https://doi.org/10.5194/nhess-15-1135-2015, 2015.

Chambre de Commerce de Dunkerque: Notice sur la ville et le port de Dunkerque, publiée par les soins de la chambre de commerce, Paul Michel, Dunkerque, 1895.

Chow, V. T.: Frequency analysis of hydrologic data, Eng. Expt. Stn. Bull. 414, University of Illinois, Urbana, Illinois, 80 pp., 1953.
Codde, R. and De Keyser, L.: Altas De Belgique, Mer du Nord Littoral/Estuaire de l'Escaut-Escaut Maritime, Comité National de Géographie, available at: http://www.atlas-belgique.be/ cms/uploads/oldatlas/atlas1/Atlas1-FR-18A-B.PDF (last access: 11 June 2018), 1967.

Coles, S.: An Introduction to Statistical Modeling of Extreme Values, Springer, Berlin, 2001.

Dalrymple, T.: Flood Frequency Analyses, Manual of Hydrology: Part 3. Water Supply Paper 1543-A, USGS, available at: http: //pubs.er.usgs.gov/publication/wsp1543A (last access: 1 December 2017), 1960.

de Belidor, B. F.: Architecture Hydraulique, Seconde Partie: L'art de Dirig Les Eaux a L'avantage de la Defense, Du Commerce et de l'Agriculture, Barrois, Hydraulica, 412 pp., 1788.

Deboudt, P.: Etude de géomorphologie historique des littoraux dunaires du Pas-de-Calais et nord-Est de la Manche, PhD thesis, Université de Lille 1, Lille, 269 pp., 1997.

De Fourcroy de Ramecourt: Observations sur les marées à la côte de flandre, in: Mémoires de mathématique et de physique, edited by: Moutard, P., Académie Royale des Sciences par divers Savans, \& lûs dans les Assemblées, Paris, 1780.

De Lalande, J. J. L. F.: Traité du flux et du reflux de la mer - d'après la théorie et les observations, Astronomie, Paris, 1781.

Derode, V.: Histoire de Dunkerque, E. Reboux, Lille, 1852.

Demotier, C.: Depuis les temps les plus reculés jusqu'à nos jours, Annales de Calais, Calais, 1856.

DREAL Bretagne: Etude Vimers des événements de tempête en Bretagne, available at: http: //www.bretagne.developpement-durable.gouv.fr/ etude-vimers-des-evenements-de-tempete-en-bretagne-a2705. html, last access: 14 March 2017.

DREAL Nord: Pas de Calais, Détermination de l'aléa de submersion marine intégrant les conséquences du changement climatique en région Nord - Pas de Calais. Phase 1: Compréhension du fonctionnement du littoral, https://www.hauts-de-france.developpement-durable.gouv.fr/ IMG/pdf/50292_-_sub_npc_-_phase_1_-_version_4.pdf, last access: 23 February 2017.

de Bertrand, R.: Notice Historique sur Zuydcoote, in Mémoires de la Société dunkerquoise pour l'encouragement des sciences, des lettres et des arts, Typographie E. Vandalle, Dunkerque, 214 $342,1855$.

Faulconnier, P.: Description Historique de Dunkerque, Bruges, Piere Vande Cappelle \& Andre Wydts, 1730.

Gaal, L., Szolgay, J., Kohnova, S., Hlavcova, K., and Viglione, A.: Inclusion of historical information in flood frequency analysis using a Bayesian MCMC technique: A case study for the power dam Orlik, Czech Republic, Contrib. Geophys. Geodesy, 40, 121-147, https://doi.org/10.2478/v10126-010-0005-5, 2010.

Garnier, E.: A historic experience for a strenthened resilience. European societies in front of hydro-meteors 16th-20th centuries, in: Prevention of hydrometeorological extreme events - Interfacing sciences and policies, edited by: Quevauviller, P., John Wiley \& Sons, Chichester, 3-26, 2015.

Garnier, E.: Xynthia, February 2010. Autopsy of a foreseeable catastrophe, in: Coping with coastal storms, edited by: Quevauviller, P., Garnier, E., and Ciavola, P., John Wiley \& Sons, Chichester, 111-148, https://doi.org/10.1002/9781119116103.ch3, 2017. 
Garnier, E. and Surville, F.: La tempête Xynthia face à l'histoire, in: Submersions et tsunamis sur les littoraux français du Moyen Âge à nos jours, Le croît Vif., Saintes, France, 2010.

Garnier, E., Ciavola, P., Armaroli, C., Spencer, T., and Ferreira, O.: Historical analysis of storms events: case studies in France, England, Portugal and Italy, Coast. Eng., 134, 10-23, https://doi.org/10.1016/j.coastaleng.2017.06.014, 2018.

Gerritsen, H.: What happened in 1953? The Big Flood in the Netherlands in retrospect, Philos. T. Roy. Soc. A, 363, 12711291,2005

Gonsseaume, C.: Un épisode de la révolution à Verton, Dossiers archéologiques, historiques et culturels du Nord et du Pas-deCalais, 27, 21-25, 1988

Grubbs, F. E. and Beck, G.: Extension of sample sizes and percentage points for significance tests of outlying observations, Technometrics, 14, 847-854, 1972.

Gumbel, E. J.: Les valeurs extrêmes des distributions statistiques, Annales de l'Institut Henri Poincaré, 5, 115-158, 1935.

Guo, S. L.: Unbiased plotting position formulae for historical floods, J. Hydrol., 121, 45-61, https://doi.org/10.1016/00221694(90)90224-L, 1990.

Guo, S. L. and Cunnane, C.: Evaluation of the usefulness of historical and palaelogical floods in quantile estimation, J. Hydrol., 129, 245-262, https://doi.org/10.1016/0022-1694(91)90053-K, 1991.

Harrau, L. A.: Rosendael, in Bulletin Union Faulconnier, société historique de Dunkerque Tome I, Union Faulconnier, Dunkerque, 218-280, 1898.

Harrau, L. A.: Histoire de Gravelines, in Bulletin Union Faulconnier, société historique de Dunkerque Tome III, Union Faulconnier, Dunkerque, 357-374, 1901.

Harrau, L. A.: Histoire de Gravelines - Chapitre 5, in Bulletin Union Faulconnier, société historique de Dunkerque Tome VI, Union Faulconnier, Dunkerque, 5-78, 1903.

Hamdi, Y.: Frequency analysis of droughts using historical information - new approach for probability plotting position: deceedance probability, Int. J. Global Warm., 3, 203-218, https://doi.org/10.1504/IJGW.2011.038380, 2011.

Hamdi, Y., Bardet, L., Duluc, C.-M., and Rebour, V.: Extreme storm surges: a comparative study of frequency analysis approaches, Nat. Hazards Earth Syst. Sci., 14, 2053-2067, https://doi.org/10.5194/nhess-14-2053-2014, 2014.

Hamdi, Y., Bardet, L., Duluc, C.-M., and Rebour, V.: Use of historical information in extreme-surge frequency estimation: the case of marine flooding on the La Rochelle site in France. Nat. Hazards Earth Syst. Sci., 15, 1515-1531, https://doi.org/10.5194/nhess-15-1515-2015, 2015.

Hirsch, R. M.: Probability plotting position formulas for flood records with historical information, J. Hydrol., 96, 185-199, https://doi.org/10.1016/0022-1694(87)90152-1, 1987.

Hirsch, R. M. and Stedinger, J. R.: Plotting positions for historical floods and their precision, Water Resour. Res., 23, 715-727, https://doi.org/10.1029/WR023i004p00715, 1987.

Holgate, S. J., Matthews, A., Woodworth, P. L., Rickards, L. J., Tamisiea, M. E., Bradshaw, E., Foden, P. R., Gordon, K. M., Jevrejeva, S., and Pugh, J.: New data systems and products at the permanent service for mean sea level, Coast. Res., 29, 493-504, https://doi.org/10.2112/JCOASTRES-D-12-00175.1, 2013.
Hosking, J. and Wallis, J.: The value of historical data in flood frequency analysis, Water Resour. Res., 22, 1606-1612, https://doi.org/10.1029/WR022i011p01606, 1986.

Hosking, J. and Wallis, J.: Some statistics in regional frequency analysis, Water Resour. Res., 29, 271-181, https://doi.org/10.1029/92WR01980, 1993.

Hosking, J. and Wallis, J.: Regional frequency analysis: an approach based on L-moments, Cambridge University Press, Cambridge, 1997.

Idier, D., Dumas, F., and Muller, H.: Tide-surge interaction in the English Channel, Nat. Hazards Earth Syst. Sci., 12, 3709-3718, https://doi.org/10.5194/nhess-12-3709-2012, 2012.

Katz, R. W., Parlange, M. B., and Naveau, P.: Statistics of extremes in hydrology, Adv. Water Resour., 25, 1287-1304, https://doi.org/10.1016/S0309-1708(02)00056-8, 2002.

Lamb, H.: Historic Storms of the North Sea, British Isles and Northzest Europe, Cambridge University Press, Cambridge, 1991.

Landrin, C.: Tablettes historiques du Calaisis, Imprimerie régionale, 1888.

Latapy, A., Arnaud, H., Pouvreau, N., and Weber N.: Reconstruction of sea level changes in Northern France for the past 300 years and their relationship with the evolution of the coastal zone, in: Coast 2017, Bordeaux, https://doi.org/10.13140/RG.2.2.14180.07041, 2017.

La Voix du Nord newspaper: 2-4 Mars 1949, Tempête sur le littoral, 1949.

La Voix du Nord newspaper: 4 Février 1953, Tragiques inondations sur les côtes de l'ouest, 1953.

La Voix du Nord newspaper: 17 September 1966, Dunkerque, Malo-lesBains, 1966.

Lefebvre: Histoire Générale et Particulière de la ville de Calais et du Calaisis Tome II, Paris, Guillaume François Debure, 1766.

Le Gorgeu, V. and Guitonneau, R.: Reconstruction de la Digue de l'Est à Dunkerque, Coast. Eng., 5, 555-586, available at: https://icce-ojs-tamu.tdl.org/icce/index.php/icce/article/ viewFile/2043/1716 (last access: 21 September 2018), 1954.

Le Gravelinois newspaper: 19 March 1898, MAD, 1898.

Le Nord Maritime newspaper: 13 January 1899, MAD, 1899.

Lemaire, A.: Ephémérides dunkerquoises revues, considérablement augmentées, Maillard et Vandenbusche, Dunkerque, 1857.

Le Tellier, J. L.: Abrégé de l'Histoire de Dunkerque, in Bulletin Union Faulconnier, société historique de Dunkerque Tome XXIV, Union Faulconnier, Dunkerque, 143-205, 1927.

Makkonen, L.: Plotting Positions in Extreme Value Analysis, J. Appl. Meteorol. Clim., 45, 334-340, https://doi.org/10.1175/JAM2349.1, 2006.

Mann, D.: Mémoire sur l'ancien état de la flandre maritime, les changements successifs, \& les causes qui les ont produits, Mémoires de l'académie impériale et royale des sciences et belleslettres de bruxelles, Académie Impériale des Sciences de BellesLettres de Bruxelles, Bruxelles, 1777.

Mann, D.: Mémoire sur l'histoire-naturelle de la mer du nord, \& sur la pêche qui s'y fait, Mémoires de l'académie impériale et royale des sciences et belles-lettres de bruxelles, Académie Impériale des Sciences de Belles-Lettres de Bruxelles, Bruxelles, 1780.

Mann, H. B.: Nonparametric tests against trend, Econometrica, 3, 245-259, 1945. 
Maspataud, A.: Impacts des tempêtes sur la morpho-dynamique du profil côtier en milieu macrotial, PhD thesis, Université du Littoral Côte d'Opale, Dunkerque, 470 pp., 2011.

Maspataud, A., Ruz, M., and Vanhée, S.: Potential impacts of extreme storm surges on a low-lying densely populated coastline: the case of Dunkirk area, Northern France, Nat. Hazards, 66, 1327-1343, https://doi.org/10.1007/s11069-012-0210-9, 2013.

Moreel, L.: Ghyvelde, Bay-Dunes à travers les Ages, in Bulletin Union Faulconnier, société historique de Dunkerque Tome XXVIII, Union Faulconnier, Dunkerque, 125-204, 1931.

Ouarda, T. B. M. J., Rasmussen, P. F., Bobée, B., and Bernier, J.: Utilisation de l'information historique en analyse hydrologique fréquentielle, Rev. Sci. Eau, 11, 41-49, https://doi.org/10.7202/705328ar, 1998.

Payrastre, O., Gaume, E., and Andrieu H.: Usefulness of historical information for flood frequency analyses: Developments based on a case study, Water Resour. Res., 47, W08511, https://doi.org/10.1029/2010WR009812, 2011.

Pouvreau, N.: Trois cents ans de mesures marégraphiques en france: Outils, méthodes et tendances des composantes du niveau de la mer au port de brest, $\mathrm{PhD}$ thesis, Université de La Rochelle, La Rochelle, 466 pp., 2008.

Plocq, M. A.: Port et Rade de Dunkerque, Impr. Nationale, Paris, 1873.

Rao, A. R. and Hamed, K. H.: Flood Frequency Analysis, CRC Press, Boca Raton, Florida, USA, 2000.

Rossiter, J. R.: The North Sea surge of 31 January and 1 February 1953, Philos. T. Roy. Soc. A, 246, 371-400, 1953.

Salas, J. D., Wold, E. E., and Jarrett, R. D.: Determination of flood characteristics using systematic, historical and paleoflood data, in: Coping with floods, edited by: Rossi, G., Harmoncioglu, N., and Yevjevich, V., Kluwer, Dordrecht, 111-134, 1994.

SHOM: Rapport technique du Projet NIVEXT: Niveaux marins extrêmes, Camille DAUBORD, Contributeurs associés: André, G. and Goirand, V., Marca Kerneis, France, 444 pp., 2015.

SHOM: Horaires de Marée, available at: http://maree.shom.fr/, last access: 10 November 2016.
Simon, B.: La marée océanique côtière, Institut océanographique, 433 pp., 2007.

Sneyers, R.: La tempête et le débordement de la mer du 1er février 1953, Ciel et Terre, 69, 97-107, 1953.

Stedinger, J. R. and Baker, V. R.: Surface water hydrology - Historical and paleoflood information, Rev. Geophys., 25, 119-124, https://doi.org/10.1029/RG025i002p00119, 1987.

Stedinger, J. R. and Cohn, T.: Flood frequency analysis with historical and paleoflood information, Water Resour. Res., 22, 785-793, https://doi.org/10.1029/WR022i005p00785, 1986.

Stephenson, A.: TideHarmonics $\mathrm{R}$ package, available at: https://cran.r-project.org/web/packages/TideHarmonics/ TideHarmonics.pdf, last access: 3 November 2017.

Union Faulconnier: Société historique de dunkerque tome XV, Union Faulconnier, Dunkerque, 1912.

Volker, M.: La marée de tempête du 1er février 1953 et ses conséquences pour les Pays-Bas, La Houille Blanche, 797-806, https://doi.org/10.1051/lhb/1953013, 1953.

Wald, A. and Wolfowitz, J.: An exact test for randomness in serial correlation, Ann. Math., 14, 378-388, 1943.

Wang, Q. J.: Unbiased estimation of probability weighted moments and partial probability weighted moments from systematic and historical flood information and their application to estimating the GEV distribution, J. Hydrol., 120, 115-124, https://doi.org/10.1016/0022-1694(90)90145-N, 1990.

Wilcoxon, F.: Individual comparisons by ranking methods, Biometrics Bull., 1, 80-83, 1945.

Wolf, J. and Flather, R. A.: Modelling waves and surges during the 1953 storm, Philos. T. Roy. Soc. A, 363, 1359-1375, https://doi.org/10.1098/rsta.2005.1572, 2005.

Zandyck, H.: Histoire météorologique et Médicale de Dunkerque de 1850 à 1860, Paris, P. Asselin, 1861. 